\title{
THE AGE PROFILE OF INCOME AND THE BURDEN OF UNFUNDED TRANSFERS IN FOUR COUNTRIES: EVIDENCE FROM THE LUXEMBOURG INCOME STUDY
}

\author{
Gary Burtless* \\ CRR WP 2005-33 \\ Released: January 2005 \\ Draft Submitted: November 2004 \\ Center for Retirement Research at Boston College \\ 550 Fulton Hall \\ 140 Commonwealth Ave. \\ Chestnut Hill, MA 02467 \\ Tel: 617-552-1762 Fax: 617-552-1750 \\ http://www.bc.edu/crr
}

\begin{abstract}
*Gary Burtless is the John C. and Nancy D. Whitehead Chair in Economic Studies at the Brookings Institution in Washington, DC. The research reported herein was performed pursuant to a grant from the U.S. Social Security Administration (SSA) to the Center for Retirement Research at Boston College (CRR). The opinions and conclusions are solely those of the author and should not be construed as representing the opinions or policy of SSA or any agency of the Federal Government, the CRR, the Luxembourg Income Study, or the Brookings Institution. The author gratefully acknowledges the excellent research assistance provided by Dan Theisen of Brookings and productive collaboration with LIS staff in Luxembourg.
\end{abstract}

(C) 2004, by Gary Burtless. All rights reserved. Short sections of text, not to exceed two paragraphs, may be quoted without explicit permission provided that full credit, including $\odot$ notice, is given to the source. 


\section{About the Center for Retirement Research}

The Center for Retirement Research at Boston College, part of a consortium that includes a parallel centers at the University of Michigan and the National Bureau of Economic Research, was established in 1998 through a grant from the Social Security Administration. The goals of the Center are to promote research on retirement issues, to transmit new findings to the policy community and the public, to help train new scholars, and to broaden access to valuable data sources. Through these initiatives, the Center hopes to forge a strong link between the academic and policy communities around an issue of critical importance to the nation's future.

\section{Center for Retirement Research at Boston College \\ 550 Fulton Hall \\ 140 Commonwealth Ave. \\ Chestnut Hill, MA 02467 \\ phone: 617-552-1762 fax: 617-552-1750 \\ e-mail: crr@bc.edu \\ http://www.bc.edu/crr}

\section{Affiliated Institutions:}

American Enterprise Institute

The Brookings Institution

Center for Strategic and International Studies

Massachusetts Institute of Technology

Syracuse University

Urban Institute 


\begin{abstract}
This paper uses micro-census income data from the Luxembourg Income Study (LIS) to measure the current and future burden of financing public transfers, especially benefits supporting the aged and near-aged. The analysis distinguishes between income obtained from households' own saving and labor earnings, on the one hand, and the part financed with unfunded transfers, on the other. The burden of unfunded transfers is defined as the tax on factor income that is needed to pay for such transfers under a balanced budget rule. The paper develops a framework for estimating and forecasting this burden using micro-census reports on the current age distribution of factor incomes, the age distribution of transfer incomes, and U.S. Census Bureau projections of the future age structure of the population. Because survey data are inaccurate and incomplete, the micro-census income reports are adjusted to reflect underreporting based on estimates of aggregate income from the national income and product accounts. Empirical estimates of current and future tax burdens are derived for four OECD countries. These show that the burden of German and U.S. transfers is unusually sensitive to the effects of an aging population. In contrast, the burden of public transfers in Finland and Britain is less sensitive to the effects of an older population because transfers in those countries are less heavily tilted toward aged beneficiaries. Factor incomes received by aged Americans are high by international standards, providing a partial offset to the sharp tilt of U.S. transfers in favor of the elderly. As the U.S. population grows older, factor incomes will decline more gradually than is the case in other rich countries, helping to maintain the size of its tax base.
\end{abstract}




\section{The Age Profile of Income and the Burden of Unfunded Transfers in Four Countries: Evidence from the Luxembourg Income Study}

The burden of population aging depends crucially on the relative sizes of the aged and working-age populations, the relative consumption of aged and working-age households, and the income sources used to pay for old-age consumption. To the extent that elderly households depend on transfers financed out of the current incomes of working-age families, the trend toward an older population can impose heavy financial burdens on active workers. If aged households pay for their current consumption largely out of their own current earnings or their own past savings, however, the burden imposed by population aging on the working-age population is considerably lighter.

Much of the cross-national analysis of the potential burden of aging populations has focused on prospective changes in the ratio of retired to working-age populations. Less attention has been directed toward measuring cross-national differences in the actual support that aged households derive from working-age households. This paper examines international differences in sources of support for old-age consumption. How much consumption is financed with aged households' own earnings and saving? How much depends on transfers from the working-age population?

Over the post-war era, rich industrialized countries have dramatically reduced the gap in average consumption between their aged and non-aged populations (Bosworth and Burtless, 1998, and Disney and Whitehouse, 2002). The improvement in the relative well-being of the elderly has been achieved through a variety of mechanisms. Aged households in all industrialized countries now derive a large fraction of their incomes from public pensions and government transfers, but countries differ widely in the proportion of old-age income that is provided through public budgets. Older people in the United States derive a comparatively modest percentage of their cash retirement income from transfers and a large percentage from private income sources, including property income, employer-sponsored pensions, and labor earnings. In a sample of 10 OECD countries, for example, analysts found that the United States ranks second in the percentage of total elderly household income derived from earnings, third in the percentage derived from property and financial assets, and ninth in the percentage derived from government transfers, including public pensions (Rein and Stapf-Finé, 2001). Because a 
large fraction of older Americans own the homes they live in, they also receive a sizeable flow of private housing services that is not reflected in their money income reports.

While several studies have examined cross-national differences in income sources in old age, none has investigated international differences in the shares of old-age consumption that is financed out of saving and own earnings, on the one hand, and out of transfers from current workers, on the other. This paper distinguishes between three basic kinds of financing for oldage consumption:

- Transfers from the public budget and pay-as-you-go pension and insurance programs;

- Own earnings of aged households; and

- Savings (including returns from property and financial assets, annuities from funded pension programs, and service flows from home ownership).

Using micro-census information on income for four countries, I derive comparable statistics on the share of old-age income that is supported with net transfers and on the part derived from aged households' own current earnings and past savings.

As a check on these calculations, I ask whether the micro-census reports of consumption flows out of saving can be reconciled with aggregate statistics on income flows. In one respect, the micro-census surveys of old-age income appear to contradict aggregate statistics on household saving. Countries with low household saving rates, including Canada, the United Kingdom, and the United States, have retirement systems that finance a comparatively large share of old-age income out of savings, including savings in funded pension systems. Countries with high household saving rates, including Germany and Japan, have micro-census surveys showing that older households derive a small percentage of their incomes from capital income flows. (For recent evidence on aggregate private and household saving, see de Serres and Pelgrin, 2002, Marquis, 2002, and Verrinder, 2002; for evidence on the role of capital income sources, see Casey and Yamada, 2003, Figure 2).

A number of explanations can account for the apparent discrepancy between microcensus evidence on old-age incomes and the aggregate statistics on ho usehold saving. First, the micro-census surveys might understate aged households' income from capital income or funded pensions, and the reporting discrepancy could be larger in some countries than others. This possibility can be examined by attempting to determine what fraction of capital income flows and funded pension payments are recorded in the micro-census files. An alternative possibility is 
that consumption flows out of saving are incompletely measured in micro-census income surveys, even when incomes are perfectly reported in the survey. For example, private home ownership gives households a flow of housing services that is not reflected in homeowners' income reports. In addition, if aged households finance part of their consumption by liquidating some of their financial and non-financial assets, the de-accumulation would not be revealed in an income survey.

A third possibility is that returns on household savings may be lower in high-saving than low-saving countries. In fact, there is some evidence that financial investments appropriate for retirement saving do yield lower returns with higher variance in Germany and Japan compared with the United Kingdom and the United States (Burtless, 2003). Moreover, compared with households in Britain and the United States, Japanese and German households tend to hold savings in low-risk, low-return assets, such as currency and bank deposits (Burtless, 2001). Low returns on capital could result in micro-census income reports that show relatively small flows of capital income in the high-saving countries. Even though aged households in high-saving countries may not derive large income flows from their savings, they may nonetheless finance a sizable share of their consumption through liquidation of capital holdings.

The remainder of the paper is organized as follows. The next section proposes a simple framework for measuring the effects of the population age distribution, the age distribution of factor income, and the age profile of pay-as-you-go (paygo) government transfer benefits on the tax burden faced by the economically active population. The framework is a natural extension and generalization of the old-age dependency ratio, a popular though misleading measure of the burden imposed by an aging population. The following section describes the micro-census survey data needed to measure household incomes, and it describes procedures to allocate individual-level incomes between components derived from own earnings and savings, on the one hand, and paygo transfers, on the other. Because incomes reported in household surveys are subject to under-reporting, procedures are also developed to adjust reported incomes so that the implied sum and distribution of household incomes are consistent with incomes recorded in the national income and product accounts. The next two sections describe empirical estimates of the age profiles of factor incomes and of paygo transfer incomes in four OECD countries. The results from these two sections are combined in the following section to develop new estimates of the tax on factor income that is needed to finance paygo transfers over the next half century. 
The estimates show that a generous social welfare system does not necessarily generate steep increases in the tax burden as the population grows older, whereas less generous social welfare systems may generate proportionately steep increases in required tax rates depending on the age profile of factor incomes and of government benefit generosity. The paper ends with a brief summary of conclusions.

\section{Old-age dependency burden}

A common way to measure the burden imposed by the aged on the working age population is to calculate the ratio of old to the number of working age adults. The Social Security Actuary performs this calculation of the old-age dependency ratio under the assumption that the working age population is between 20 and 64 years old. The Actuary's calculations show that in 1950 there were 14 Americans past age 64 for every 100 adults between 20 and 64 years. The aged dependency ratio rose to 21 by 2000, and the Actuary's intermediate forecast suggests it will reach 38 by 2050 (OASDI Trustees, 2004, p. 78).

Under stylized assumptions regarding the pension formula and work patterns among the young and the old, the trend in the old-age dependency ratio will parallel the trend in the payroll tax rate needed to finance retirement benefits. In a pay-as-you-go pension program, the taxes imposed on current wage earnings are just sufficient to pay for benefits provided to the retired population. Assuming all aged adults receive a pension and all working-age adults are employed, a balanced-budget rule in the pension program requires that current benefit payments must equal tax revenues:

$$
\text { (1) } \quad \mathrm{P} a_{2}=\mathrm{t} \mathrm{W} a_{1}
$$

where $\mathrm{P}=$ Average pension benefit;

$\mathrm{W}=$ Average wage;

$\mathrm{t}=$ Tax on wages;

$a_{1}=$ Proportion of population that is working age; and

$a_{2}=$ Proportion of population that is aged.

$$
\text { (2) } \mathrm{t}=\frac{\mathrm{P}}{\mathrm{W}} \frac{a_{2}}{a_{1}}
$$

In other words, the tax rate needed to maintain paygo solvency is the old-age dependency ratio times the ratio of the average benefit payment to the average wage. If a pension formula sets the average benefit payment so that it is a fixed percentage of the average wage, the paygo tax rate, 
$\mathrm{t}$, needed to support the pension program will vary over time in proportion to the old-age dependency ratio, $a_{2} / a_{1}$. An increasing share of the aged in the population will inevitably boost the percentage of earnings that must be set aside to pay for benefits to the elderly.

A rising old-age dependency ratio can be associated with other effects on public spending however. Partly offsetting higher spending needs for the dependent old is the shrinking need to provide support to the dependent young. Some of this burden is financed through public budgets, primarily as spending on schools and universities. Government spending on education represented 5.1 percent of U.S. GDP in 2000, about one-half percentage point less than spending in 1975, when the percentage of the population between ages 5 and 24 was near a post-war high. If spending for the young is partly financed by taxes imposed on earnings, the combined tax to pay for pensions and education will bear a less direct relationship to the old-age dependency rate than the relationship implied by equation 2. Of course, government transfers and other public spending are not provided only to the young or the old. Many working-age adults also derive support from government transfers. Nor are the taxes used to pay for transfers imposed solely on wages. Means-tested government transfers and most public health insurance benefits are financed out of general government revenues, which are derived from taxes on personal income, property, and consumption as well as on labor earnings.

If transfers are financed with a proportional tax on all factor income, the balanced-budget tax rate needed to pay for age-related transfers can be expressed as

$$
\mathrm{t}=\frac{\mathrm{P}_{T O T}}{\mathrm{~W}_{T O T}+\mathrm{R}_{T O T}}=\frac{\mathrm{S} a_{i} \mathrm{P}_{i}}{\mathrm{~S} a_{i}\left(\mathrm{~W}_{i}+\mathrm{R}_{i}\right)}
$$

where $\mathrm{P}_{i}=$ Average transfer benefit received by persons in age group $i$;

$\mathrm{W}_{i}=$ Average labor income earned by persons in age group $i$;

$\mathrm{R}_{i}=$ Average capital income earned by persons in age group $i$;

$\mathrm{t}=$ Tax rate on total factor income, $\mathrm{F}_{T O T}=\mathrm{W}_{T O T}+\mathrm{R}_{T O T}$;

$a_{i}=$ Proportion of population in age group $i$.

Note that an age group's average factor income, $\mathrm{F}_{i}$, is simply the sum of its average wage income, $\mathrm{W}_{i}$, and average capital income, $\mathrm{R}_{i}$. It is convenient to express the age profile of factor income by reference to the mean factor income received by the age group that receives the highest factor income, say, $\mathrm{F}_{M} . M$ can be interpreted to mean "middle aged," since income from earnings and capital usually reaches a peak when people attain middle age. If there are $N$ age 
groups and we define $f_{i}=\mathrm{F}_{i} / \mathrm{F}_{M}$, then the age profile of factor income is indicated by the sequence $f_{1}, f_{2}, f_{3}, \ldots, f_{M}, \ldots, f_{N}$, where each $f_{i}$ is the mean factor income in group $i$ expressed as a fraction of the factor income received by a middle-aged person and $f_{M}=1$. Suppose that the average transfer benefit paid to a particular age group $i$ is also measured relative to the mean factor income received by a middle-aged person. If $\beta_{i}=\mathrm{P}_{i} / \mathrm{F}_{M}$, we can re-write equation (3) as

$$
\mathrm{t}=\frac{\mathrm{S} a_{i} \mathrm{P}_{i}}{\mathrm{~S} a_{i} \mathrm{~F}_{i}}=\frac{\mathrm{S} a_{i} \beta_{i} \mathrm{~F}_{M}}{\mathrm{~S} a_{i} f_{i} \mathrm{~F}_{M}}=\frac{\mathrm{S} a_{i} \beta_{i}}{\mathrm{~S} a_{i} f_{i}}
$$

The paygo tax rate needed to support the transfer system is therefore a function of the age distribution of the population, $a_{1}, a_{2}, a_{3}, \ldots, a_{N}$, the age profile of factor income, $f_{1}, f_{2}$, $f_{3}, \ldots, f_{N}$, and the relative generosity of transfer payments compared to average factor income of the middle-aged, $\beta_{1}, \beta_{2}, \beta_{3}, \ldots, \beta_{N}$. If the age distribution is skewed toward groups with low benefit payments and high factor incomes, the tax needed to finance paygo transfers will be low. As a graying population increases the proportion of people with high benefit requirements and low factor incomes, $\mathrm{t}$ must rise.

The effect of population aging can be illustrated with a simple example. Suppose the adult population is divided into four age groups: the young (between ages 15 and 34), the middle-aged (between 35 and 54), the near-elderly (between 55 and 64), and the elderly (ages 65 and older). In addition, assume the age profiles of factor income and of paygo benefit payments follow the schedules shown in Figure 1. Both factor incomes and benefit payments are measured relative to the average factor income received by people between 35 and $54 .{ }^{1}$ The two bars on the right show the population average factor income (66) and average transfer payment (14). The implied tax rate needed to support paygo benefits out of factor incomes is thus about 21 percent $(14 \times 100 / 66)$. Given the pronounced tilt in the age distribution of factor incomes and benefit payments, it is obvious that shifts in the population age structure can affect average benefit payments, factor incomes, and the ratio of the se two variables.

\footnotetext{
${ }^{1}$ The age distributions of factor incomes and benefit payments in Figure 1 represent the average distributions observed in the four countries analyzed in this paper - Finland, Germany, the United Kingdom, and the United States. The population average factor income and benefit payment are derived using age group weights that reflect the average age distribution of these four countries in 2000 .
} 
Consider the effects of a shift in the age distribution that mirrors the expected change that will occur in industrialized countries between 2000 and 2050. As a percentage of the total population, the population age 65 and older will increase from 18 percent to 33 percent over that interval. $^{2}$ If each age group had an identical factor income equal to the overall population average in 2000, the shift in the age composition of the population would have no impact on average factor incomes. Because the population will shift toward age groups that earn lower incomes, however, by 2050 the tax rate will have to rise 2.5 percentage points (about 12 percent) above the required level in 2000 in order to compensate for the lower factor incomes that will be earned by the older population. Similarly, if each age group received an identical average transfer payment, the shift in the age structure of the population would have no impact on the average transfer payment the government has to pay out. The actual age profile of benefit payments slopes upward with age, however, implying that the average transfer will have to rise. Because the population will shift toward age groups that receive larger benefits, by 2050 the tax rate must rise 7 percentage points (about 33 percent) to pay for higher average benefits. In addition, there is a small interaction effect between factor incomes and the benefit schedule that boosts the required tax rate a bit more. The total increase in $\mathrm{t}$ needed to support paygo transfers between 2000 and 2050 is a little more than 10 percentage points, about 48 percent of the 2000 tax rate. Figure 2 shows the trend in $\mathrm{t}$ between 2000 and 2050 under the assumption that the population age structure follows the trend predicted by the U.S. Census Bureau for a handful of industrialized countries. The figure also shows a decomposition of the tax rise between the part traceable to changes in the factor income distribution, the part due to higher benefit obligations flowing from the age profile of transfer payments, and the interaction effect. The bulk of the increase in required tax contributions is clearly due to the steep age profile of benefit payments.

Much of the cross-national literature on population aging focuses on the impact of a changing age structure on the burden of supporting an older population. As indicated in equation 4, however, the effect of aging also depends on the age distribution of factor incomes and the relative generosity of public transfers over the life cycle. If young people receive generous support under the transfer system, population aging may initially reduce tax burdens as the share of the population in young age groups declines (see Cutler et al., 1990, and Burtless, 2002). The

\footnotetext{
${ }^{2}$ These estimates reflect the unweighted average population trends in Finland, Germany, the United Kingdom, and the United States as predicted by the U.S. Census Bureau (2004).
} 
young earn little income from wages and property, so a decline in fertility will initially reduce the relative size of an age group that has limited factor income and increase the relative importance of age groups with high labor or capital incomes. Two countries with an identical age distribution and identical trends in the age structure may face very dissimilar trends in tax burdens. Differences in the age pattern of factor incomes or in the age pattern of transfer generosity can produce marked differences in the trend of $t$, even when the population-average level of transfers compared with factor incomes is initially quite similar. To take a simple example, a nation that provides little public income support to young or middle-aged adults and offers generous support to the population past 65 faces a much steeper increase in taxes when old-age dependency rises than does a nation providing moderate income support to young, middle-aged, and elderly alike.

\section{Measuring incomes}

This paper takes two approaches to measuring the tax burdens needed to support pay-asyou-go transfers in industrialized countries. Under the first approach, I rely solely on microcensus data to approximate the capital and labor incomes and the paygo transfer incomes received by people classified according to age. The micro-census tabulations in turn provide estimates of the benefit ratios, $\beta_{i}$, and age profiles of factor incomes, $f_{i}$, needed to calculate $t$. The time trend in tax burdens can then be computed using demographic projections of the future population age structure. If the micro-census survey responses are accurate and complete, they provide a reliable guide for estimating the current tax on factor incomes needed to support paygo transfers. Their usefulness for predicting future tax burdens is more problematical, since future benefit ratios, $\beta_{i}$, and factor income profiles, $f_{i}$, may change as a result of population aging. Nonetheless, the projected values of $t$ offer a convenient starting point for assessing a country's potential burden assuming that its economic and political institutions remain unchanged.

Micro-census data suffer from a number of shortcomings that make them inaccurate or incomplete. In most countries the data are collected in household interviews conducted by a national census agency or some other survey organization. In only a handful of countries are the data obtained from administrative records of the tax collection or social security agency. In countries that rely on household interviews, some respondents do not agree to be interviewed. Others fail to answer all the questions posed by an interviewer or supply inaccurate information. 
Equally important, the survey questions do not provide a complete tally of relevant household income. Some elements of employer compensation and self-employment income are not covered by the questionnaire. A large percentage of capital income is missed by most household surveys. Respondents may not be asked about their share of investment earnings in insurance or pension programs in which they participate. Few household surveys elicit enough information about consumer durables or owner-occupied homes to allow researchers to calculate accurately the value of capital services that owners derive from property they own. To compensate for the shortcomings of the survey data, a second method is also used to calculate the tax rate needed to finance paygo transfers. I make adjustments in the survey responses to increase the reported income amounts up to known totals reflected in a country's national income and product accounts (NIPA). These adjustments are much more important for some income sources, such as self-employment earnings and property income, than they are for others. Moreover, underreporting in household surveys is a more serious problem in some countries than others. After household survey data are adjusted to reproduce income totals shown in each country's NIPA, the estimates of $t$ will be more comparable from one country to the next.

Using either methodology, the principal source of information on the age distribution of factor and transfer income comes from a household micro-census survey. Survey data of this kind are obtainable for 25 countries participating in the LIS. ${ }^{3}$ This paper examines 1999-2000 income patterns in four LIS member countries: Finland, Germany, the United Kingdom, and the United States. These countries were selected because they are reasonably large, they have similar levels of per capita income, and they span an interesting range of social policy and demographic experience. Although the population of each of the countries will grow older during the next half century, aging will occur at a different rate in each country (see Figure 3 ). It would be desirable to include a broader cross-section of countries in the comparison. Some important countries, including Japan, do not supply micro-census data to the LIS. Others, like France and Australia, have not yet submitted files to the LIS covering incomes received in years after 1994. And still other LIS countrie s have submitted files that omit some income or wealth data that are crucial for this analysis.

\footnotetext{
${ }^{3}$ For details about LIS data sets and documentation of the main variable definitions, readers are referred to http://www.lisproject.org.
} 
To estimate the critical parameters in equation 4 , it is necessary to measure income separately within age groups and to distinguish between income that is derived from factor income and from paygo transfers. The distinction between factor income and paygo transfers is not the same as the usual distinction between income derived from public and private sources. Retirement income that is obtained from a funded pension system, whether the funds are managed in the public or private sectors, represents factor income. Consider a public pension program run in behalf of government employees. If the program collects contributions from public workers and their employers, invests those funds in a separate investment account, and then pays retirement benefits out of past contributions and investment earnings of the fund, the retirement income derived from the program represents factor income. From an economic standpoint, there is no practical difference between this kind of retirement income and income that is derived from an investment portfolio maintained by a private insurance company or savings bank. In both cases, incomes are obtained from the stream of factor payments generated by a capital investment.

The LIS data set provides detailed information about a variety of public and private income sources, including wages and salaries, net income from self-employment, property income including interest, dividends, and rent, occupational pensions, means-tested benefits, and public retirement benefits. In most cases it is straightforward to distinguish between income sources that represent factor income and those representing paygo transfers. Wage and salary income and most employer supplements to wages and salary represent a return for labor services. I also classify self-employment income as labor income, though for many entrepreneurs selfemployment income partly reflects the return on capital investment. Means-tested benefits and public pensions from unfunded public programs, including the U.S. and German social security systems, the U.K. basic state pension, and the Finnish flat-rate pension scheme, clearly represent varieties of paygo transfers. In contrast, occupational pensions in Germany, the United Kingdom, and the United States are classified as factor income. This classification seems justified for the United States, even in the case of occupational pensions offered by public employers, because the private and public employer-sponsored pension programs are overwhelmingly capital funded (Bosworth and Burtless, 2004). ${ }^{4}$ Finland's occupational pension

\footnotetext{
${ }^{4}$ The classification is less clear in Germany, because until recently occupational pensions offered by private employers were mainly financed out of company book reserves rather than segregated investment
} 
system represents a hybrid or partially funded program. I classify one-quarter of Finnish occupational pensions as factor income and three-quarters as paygo transfers.

In principle it would be desirable to measure all income paid to an individual household (or to its agents) that represents returns on capital or labor services. The total should include all compensation paid in behalf of a wage and salary worker, including money and in-kind supplements to ordinary money wages as well as the compulsory taxes or contributions employers are obliged to pay for public social insurance. Supplements to wage income include voluntary and compulsory contributions for occupational pensions and for health, injury, and life insurance. Unfortunately, very few workers can accurately estimate how much their employers pay for these earnings supplements, so the LIS wage data usually reflect gross money wages before subtractions for the employee's own tax payments and social insurance contributions. The LIS data for the United States, which are extracted from the U.S. Census Bureau's Current Population Survey (CPS) files, include Census Bureau imputations to reflect most employer contributions. Because similar data are not available for the other three countries, however, the U.S. data on employer contributions have not been used here.

In addition to reported interest, dividends, and rental income, capital returns should include the investment income earned on insurance company and pension fund reserves held in behalf of individual survey respondents. For example, the interest income earned in a funded life insurance policy should be included as capital income, and the interest and dividend income earned on a respondent's share of pension fund reserves should be incorporated in a household's factor income. Not surprisingly, few respondents know the value of these income items, so they are not reflected in the LIS data file. The capital income of a homeowner should include all or part of the flow of housing services that the owner derives from ownership of a home. In the case of Finland, Germany, and the United States, the LIS files include estimates of the return that homeowners derive as a result of ownership of a house. Unfortunately, the imputations are based on different procedures in different countries. In Finland and Germany, the estimates reflect an assessment of the rental income a homeowner would receive if his or her home were rented in the private market. In the United States, the U.S. Census Bureau imputes equivalent rental income based on the assumed financial return that homeowners could earn on the net

accounts. However, occupational pensions are relatively unimportant in German. Most pension income comes from unfunded public programs and represents a paygo transfer. 
equity they hold in their homes (that is, the difference between the market value of their home and the balance on their home mortgage). I was able to make an imputation of rental income for U.K. homeowners based on the same procedure used by the U.S. Census Bureau. I based this imputation on my own tabulations of home values and mortgages in the 1999 British Household Panel Survey. ${ }^{5}$ No imputations have been made in this study to reflect the flow of capital services that LIS respondents enjoy as a result of owning consumer durables, such as household appliances, cars, and furniture. Since ownership of these items increases as people get older, the absence of data on consumer durables will lead to an understatement of the true capital incomes of the middle-aged and elderly. As we shall see below, the aggregate capital income reported in the LIS is considerably smaller than capital income totals shown in the NIPA, even ignoring the issue of consumer durables.

Having classified the income items in categories corresponding to labor returns, capital returns, and pay-as-you-go transfers, the next step is to allocate income items to individuals based on their age. Income items representing the great majority of total income, including wages and salaries, self-employment earnings, and occupational pensions, are reported in LIS files on an individual basis. It is therefore straightforward to allocate these items to appropriate income recipients and age groups. Other income sources, including many forms of property income and some paygo transfers, are only reported at the household level. If a household contains several adults, it is not always obvious which individual is the owner of a particular property or the recipient of a particular household income item. The analysis that follows is based on a simple allocation procedure. Income items reported in the LIS "person file" were allocated to the person who reported receiving them. Income items reported only in the LIS "household file" were divided equally between the household head and his or her spouse. When a household is headed by a single person, the head is assumed to be the sole recipient of all "household" income items. If more than one generation of adults lives in the same residence, this procedure may produce a misallocation of some household income items. For example, if certain paygo transfers are recorded only in the LIS household file rather than in the person file,

5 The Census Bureau imputations of equivalent rental income for U.S. homeowners subtract an estimate of the property tax owners must pay on their home. However, this subtraction is not made in the LIS income files for Finland and Germany. To make our estimates of equivalent rental income similar across the four countries, the estimates of equivalent rental income for the United States therefore make no subtraction for property taxes. 
the procedure will allocate the transfer to the person who is identified as the household head, even though another adult may be the actual recipient. Since there are comparatively few multigeneration households in the four countries studied here, it seems unlikely the misallocation of income will be significant.

Table 1 shows estimates of factor incomes and paygo transfers in 1999 or 2000 for the four countries included in this study. The income totals reported in rows $1,3,5,7$, and 8 are estimates derived from the LIS files. They were obtained by multiplying LIS respondents' income reports by the population weights contained in the LIS file and then summing to find implied income totals. Lines 2, 4, 6 and 9 show equivalent national income totals derived from the OECD National Accounts data base. A comparison of lines 1 and 2, for example, allows us to see how much of the aggregate employee compensation recorded in the NIPA is reflected in LIS wage and salary reports. The difference between the aggregate totals does not necessarily reflect income under-reporting in the LIS file. As noted above, employee compensation includes employer social contributions and supplements to wages that are not reflected in the money wages received by employees.

The lower panel of Table 1 shows direct comparisons between LIS income items and equivalent items in the NIPA. Wages and salaries reported in LIS represent 76 percent to 81 percent of the compensation recorded in NIPA. This implies that 24 percent to 19 percent of factor income derived from wage and salary employment is missed in the LIS files. The percentage of aggregate income missing in the LIS is often much bigger for other income items. Moreover, the percentage of missing income varies across countries. Self-employment income appears to be very well reported in Finland and the United Kingdom, but it is apparently subject to massive under-reporting in Germany and the United States. The amount of true underreporting may be less variable than this comparison implies. In fact, net self-employment income reported in the U.S. household survey is reasonably close to the amount reported to the tax authorities and the Social Security Administration. It differs widely from the amount shown in the NIPA because U.S. statistical authorities believe the income tax records and household survey data reflect too little of the economic income that sole proprietors earn from their businesses. In effect, the NIPA estimate of proprietors' income represents a guess by the U.S. statistical authorities. The statistical authorities in Finland and the United Kingdom probably use 
a different method to estimate the total income received by the self-employed, and they may place greater faith in the reports supplied to tax authorities and census interviewers.

The lower panel shows wide national differences between capital income flows reported in the household surveys and the NIPA. Only in Finland is LIS-reported capital income substantially more than half the capital income flows recorded in the NIPA. ${ }^{6}$ In Germany, less than one-fifth of NIPA capital income is reflected in the LIS files. Readers should bear in mind that the NIPA income total reflects interest, dividends, and rent payments attributable to households, even if the households do not directly receive these income flows as cash payments in the current year. The income may be earned in accounts directly or indirectly owned by households, as insurance policies or pension accounts. On the other hand, the LIS capital income estimates include occupational pension payments, which for most households will differ from the annual income amounts that households actually earn in capital income. A pension annuity contains a repayment of past principal contributions and past accrued investment income as well as current interest payments. In the LIS tabulations, occupational pension annuity payments are classified as capital income flows, but the payments to individual households do not really correspond to capital income flows as those flows are measured in the NIPA. Obviously, any adjustment of the LIS capital income reports to bring them closer to the aggregate income flows in the NIPA will substantially boost the measured incomes of capital owners in Germany and the United States.

The bottom row in Table 1 shows the percentage of NIPA-recorded government transfer payments that are reflected in the LIS files. Transfer incomes are apparently better reported in Finland and the United Kingdom than they are in Germany and the United States. Part of the reason for the difference between LIS income reports and the NIPA is the difficulty of measuring many government transfers, especially in-kind transfers such as medical insurance and health care. The U.S. Census Bureau imputes estimates of the value of government-provided health insurance under the Medicare and Medicaid programs. If these imputations were included, the total government transfer payments included in the LIS files for the United States would rise to $\$ 776.2$ billion, or about three-quarters of the government transfers shown in the NIPA.

\footnotetext{
${ }^{6}$ The exceptionally good capital income reports in Finland may be a byproduct of my division of occupational pensions between capital income and paygo transfers. I assume that one-quarter of occupational pensions are attributable to capitalfunded pension accounts. If the true percentage is lower, the amount of capital income reported in Finland's LIS file would be lower, too.
} 
Estimates of this kind are not available for the other three countries. Because health care transfers are one of the most important excluded categories of government benefits and because these transfers are disproportionately received by older citizens, it is likely that the LIS files understate the relative importance of transfer income to aged households. This issue can be examined in the case of the United States, because the LIS / CPS household data files contain estimates of the insurance value of government medical benefits.

\section{The age distribution of factor incomes}

All information about the age distribution of factor income and transfer payments is based on interview responses in the LIS data files. Figure 4 shows the age distribution of factor income in the four countries, using the average factor income received by 45-49 year-olds as a benchmark for comparison. Average incomes are shown for people in five-year age groups starting at age 15 . Children under 15 receive virtually no capital or labor income, and hence they are excluded from these and all subsequent calculations. ${ }^{7}$ The age profile of factor income is broadly similar in all four countries. Factor income reaches a life-cycle peak shortly before age 45 in Finland, between ages 45-49 in Germany, and at a slightly older age in Britain and the United States. The age profile shows a characteristic pattern of steep increase between age 15 and early middle age, a leveling out or small increase between the late 30 s and early 50s, and then a steep decline after age 55. Nearly all of the decline after age 50 is traceable to a fall in labor earnings, represented by the dark bars in Figure 4. Note that the profiles displayed in Figure 4 reflect only the factor incomes actually earned by adults at successive years of age. Because of income sharing among relatives, the estimates do not necessarily reflect the actual incomes available to pay for consumption in any age group. Young adults earn very little factor income, since many of them are enrolled in schoolor have just begun to earn wages for the first time in their lives. Part or all of their consumption may be financed from the factor incomes received by parents or other middle-aged relatives. Inter-family transfers may also be important

\footnotetext{
${ }^{7}$ Households may receive government transfers, such as child allowances or government earnings subsides, as a result of the presence of children. Such income is typically recorded as being paid to an adult member of the household or is classified in the LIS data files as a "household" income item. If it is classified as the latter kind of item, I have divided the income equally between the household head and spouse of head. In the remainder of this analysis, I ignore the effect of children on the age profile of factor and transfer incomes. The tabulations focus solely on the impact of the age distribution of the population that is 15 and older.
} 
to some adults past the age of 65 , although inter-family transfers are nowadays much less significant for this age group than was true in the past.

Figure 4 and the top panel of Figure 5 show that labor income falls off more gradually after age 60 in the United States than it does in the other three countries. Americans rely more heavily on labor income in old age than citizens of other industrialized countries. For example, Americans between 65 and 69 earn labor incomes that are about 20 percent of the average factor income received by Americans who are between 45 and 49 years old. The comparable percentage in Britain, Finland, and Germany is just 5 percent. Even between ages 75 and 79 Americans earn labor incomes that are equivalent to 6 percent of the average factor income of 45-49 year-olds, whereas the comparable percentage in Britain, Finland, and Germany is only about 1 percent. This means that U.S. labor income is somewhat less sensitive to shifts in the old-age dependency ratio than earned income in other rich countries.

The lighter portion of each bar in Figure 4 represents income derived from capital income sources - interest, dividends, rent, funded pension payments, and imputed rent on owneroccupied homes. Unlike labor income, capital income continues to rise through ages 70 or 75 . Capital income is relatively more important for older adults in Britain and the United States than it is in Finland or Germany (see also the lower panel of Figure 5). In the United Kingdom and the United States, the average capital income reported among people past 65 is more than twice as high as it is among adults between 45 and 49. Capital incomes received by the aged in Finland and Germany are relatively much smaller. One implication of this comparison should be obvious. If the future age distribution of capital income remains similar to the distribution observed in 2000, the trend toward an older population will boost capital income more in the United Kingdom and the United States than it does in Finland or Germany.

The top panel of Figure 6 provides a four-country summary of the age profile of total factor income. The chart shows sizeable inter-country differences in the profile of factor incomes, especially past age 55. U.K. and U.S. residents receive significantly higher factor incomes than residents of Finland and Germany once they reach late middle age. According to income reports in the LIS files, the total factor income received by $70-74$ year-olds represents 38 percent of the average factor income of an American between ages 45 and 49. In Germany and Finland the comparable percentages are just 13 percent and 23 percent, respectively. If this age pattern persists over the next half century, Germany and Finland can expect to see a dramatic fall 
in the availability of factor income as their populations age. The decline in factor income associated with population aging will be more gradual in the United Kingdom and the United States, even if the trend toward an older population is the same in all four countries.

Adjustment for under-reporting. The aggregate incomes reported in the LIS income files are smaller - often substantially smaller - than income totals shown in the NIPA. Since the shortfall in aggregate income differs across countries and across different types of income, it is useful to check the LIS estimates using income totals adjusted to reflect possible under-reporting in the household surveys. To perform this check, I assume that under-reporting represents a constant proportional share of income across all age groups, while the proportional amount of under-reporting differs across different types of income. Most of the data needed to make this adjustment for under-reporting are displayed in Table 1. The adjustment for under-reporting of wage and salary compensation, for example, can be calculated using information in rows 1 and 2 of the table. Row 1 shows aggregate wage and salary income reported in the LIS data file, and row 2 shows total compensation, including wage supplements and mandatory contributions for social insurance, reported in the NIPA. To compensate for the LIS income shortfall, I multiply LIS wage and salary income amounts by the ratio of the entries in row 2 and row 1 . For example, just 78 percent of the compensation paid to wage and salary workers in Finland is recorded as wage and salary income in Finland's LIS file. By increasing LIS-reported wage and salary income by 29 percent, the adjusted total wage and salary income in the LIS file would exactly match the wage and salary compensation reported in the NIPA. This procedure is used to adjust LIS labor incomes and transfer payment incomes.

A slightly different procedure is used to adjust capital incomes. In calculating capital income in the LIS, it has been assumed that some or all occupational pensions represent a return to capital. As noted earlier, however, this treatment of pension income does not correspond with the treatment of capital income in NIPA. The NIPA statistics credit households with interest, dividend, and rental income when interest, dividends, and rents are received by the pension funds and insurance policies owned by households. This does not occur at the same time as households actually receive annuity payments from their pensions or when payments are made for insurance claims. Using only the information available in the LIS files, it is impossible to allocate reliably all of the capital income shown in the NIPA to individual ho useholds. I assume, however, that NIPA-estimated interest, dividend, and rental income is distributed across age 
groups in the same way as interest, dividend, and rental income reported in the LIS. While there is no reason to think this is exactly true, it offers a straightforward way to adjust LIS-reported capital incomes so that the aggregate total is the same as that shown in the NIPA. Note that the procedure ignores funded pension payments recorded in the LIS. The adjustment to LIS capital income assumes that an equal proportional adjustment is needed for all interest, dividend, and rental income reported in the household survey file. Except for the United States, I was not able to find NIPA estimates of the flow of rental services from owner-occupied homes. I have therefore included LIS estimates of these flows without any adjustment when calculating a household's total capital income.

In sum, except for rental incomes on owner-occupied homes, capital and labor incomes reported in LIS are adjusted to bring the implied aggregate totals up to corresponding estimates in a country's NIPA. The plausibility of the adjustment depends on the assumption that the aggregate incomes reported in the NIPA are more accurate than those reflected in the unadjusted LIS survey files. The adjustment to LIS incomes will be valid to the extent that income underreporting in the household data files is proportionately the same in all age groups. If underreporting of a particular income item represents a more severe problem for aged households, the adjustment will produce an understatement of the relative incomes of the aged.

The implication of the adjustment for the age profile of factor incomes is shown in the lower panel of Figure 6. On the whole, the adjustments have little effect on our interpretation of cross-national differences in the age profile of factor incomes. As is the case when the tabulations are performed with unadjusted LIS incomes, the adjusted-income calculations show that American and British households derive much higher factor incomes in old age than do their counterparts in Finland and Germany. Nonetheless, the income adjustments produce a sizeable increase in the apparent importance of factor incomes for aged Germans. Measured as a fraction of the factor incomes received by 45-49 year-old Germans, the importance of factor incomes for elderly Germans approximately doubles when the calculations are performed with incomes that have been adjusted for under-reporting. The jump in the importance of factor incomes among older Germans should not be surprising given the pattern of under-reporting reflected in Table 1. Because of under-reporting of German incomes, very large adjustments must be made in reported amounts from self-employment and interest, dividends, and rent. All of these income sources are relatively more important among older people than among the young and middle- 
aged. In contrast, the adjustment for under-reporting of German wage and salary income is comparatively small, and this income source is relatively much more important for the young and middle-aged. Even with large adjustments in the factor income received by older Germans, it remains the case that factor income is a more important income source for the aged in Britain and the United States than it is in Germany. If this difference persists in the future, the decline in factor income resulting from population aging should be smaller in Britain and the United States than it is in Germany or Finland.

\section{The age distribution of government transfers}

The tax burden of supporting paygo transfers depends on the relative generosity of the transfer system as well as the age distribution of factor incomes. In equation 4 , the age profile of transfer generosity, $\beta_{1}, \beta_{2}, \beta_{3}, \ldots, \beta_{N}$, measures average benefit payments received by an age group, $i$, relative to the average factor income received by a middle-aged person, here assumed to be someone between ages 45 and 49 . Figure 7 shows estimates of $\beta_{i}$ at successive ages in the four countries. The top panel displays estimates calculated using the unadjusted income amounts reported in the LIS household survey files. The lower panel shows estimates based on LIS income reports that are adjusted to reproduce the aggregate income totals reflected in each country's NIPA data.

For each type of calculation, I have made two estimates of the age profile of transfer income for the United States. The basic U.S. tabulation uses the LIS income reports of cash and near-cash transfer income, either without any adjustment (the top panel of Figure 7) or with an adjustment to bring total paygo transfers up to the aggregate amount of "social benefits, receivable" recorded in the NIPA. These U.S. estimates are therefore calculated in the same way as the equivalent estimates for Finland, Germany, and the United Kingdom. For the United States, we also have micro-census estimates of the value of Medicare and Medicaid health insurance for people who are insured by those programs. When these estimates of health insurance transfers are added to other paygo transfers, it is possible to obtain a more complete assessment of the cost of government transfers. The estimates shown in Figure 7 that are labeled "USA (2)" reflect alternative estimates of the age profile of transfer income that is based on the supplemental information about Medicare and Medicaid transfers. In the top panel, the estimates of Medicare and Medicaid transfers are included in the calculations without any adjustment. In 
the bottom panel, they are adjusted to bring U.S. total transfer income, including other cash and near-cash transfers, up to the total "social benefits, receivable" recorded in the U.S. NIPA. ${ }^{8}$

Consider first the estimates that are based on unadjusted LIS income reports, shown in the top panel of Figure 7. These estimates show that Finnish transfers are uniformly the highest up through ages 65-69. After that age, German transfers are relatively the most generous. Interestingly, at ages between 15 and 54 British transfers are more generous than those provided in Germany or the United States. By age 65-69, U.K. transfers are significantly less generous than the benefits provided by the other two European countries. Transfers in the United States are notably less generous for working-age adults than they are in the three European countries, but the relative generosity of transfers to the elderly depends crucially on whether imputed Medicare and Medicaid are included in the estimate of paygo transfers. When Medicare and Medicaid are included, transfers to America's elderly are more generous than those provided to the elderly in the United Kingdom. When Medicare and Medicaid are excluded from the tabulations, the United States offers the least generous paygo transfers at every age, including ages past 65 .

Although any plausible definition of paygo transfers ought to include benefits provided in the form of public health insurance, it is not obvious whether it is appropriate to compare U.S. estimates that include imputed Medicare and Medicaid payments with European transfer estimates that exclude any imputation for public medical insurance. Public spending on health in 2000 was 5.0 percent of GDP in Finland, 5.8 percent in the United States, 5.9 percent in the United Kingdom, and 8.3 percent of GDP in Germany (OECD, 2004). Most public spending on health care takes the form of payments to support medical insurance for individuals. Since the cost of providing health care rises steeply with age in all developed countries, government transfers will be more heavily tilted toward the aged when public health insurance is included than when it is excluded (Cutler and Sheiner, 2001, and Sheiner, 2004). The estimates labeled "USA (2)" reflect this tilt for the United States, but the other estimates in Figure 7 exclude any valuation of public health insurance benefits.

\footnotetext{
${ }^{8}$ In other words, the estimates in the lower panel labeled "USA (2)" are derived under the assumption that U.S. paygo transfers are distributed in the population in the same way as the sum of cash and near-cash transfers plus Medicare and Medicaid benefits. The total amount of these benefits is assumed to be understated in the LIS files by a uniform percentage for each household. The percentage adjustment for under-reporting is the percentage needed to bring total cash and near-cash transfers plus Medicare and Medicaid up to the total amount recorded in the U.S. NIPA.
} 
Inspection of the lines labeled "USA" and "US A (2)" shows that the inclusion of public health benefits makes a big difference in the age profile of U.S. transfer benefits. Including public health insurance in the other three countries would obviously affect the results for those countries as well. However, it is unlikely that the effect on the age distribution of transfers would be as big in Europe as it is in the United States. Most working-age Americans and their children obtain health insurance from employer-provided plans and with premiums paid out of their cash incomes. In other words, most insurance for these groups is purchased directly out of the factor incomes of working-age adults. Public health insurance is important mainly for poor and aged Americans, so the age profile of public health insurance benefits is heavily tilted toward the aged. In contrast, most European public health insurance offers coverage to children and working-age adults as well as to the poor and aged. European government spending on this kind of transfer income is thus likely to be less tilted toward the aged than it is in the United States.

The lower panel of Figure 7 contains a recalculation of the age profile of transfer generosity after applying an adjustment to LIS income reports to bring total factor and transfer incomes up to the amounts shown in official NIPA statistics. Finland and the United Kingdom continue to be ranked as the most generous countries in transferring incomes to the young and the middle-aged, but Britain's rank in generosity toward the elderly falls from third to last place. The increase in the relative generosity of U.S. and German transfers when adjusted incomes rather than unadjusted incomes are used is due to the different patterns of under-reporting in those countries. A very large upward adjustment of transfer incomes is needed to bring LIS incomes in the United States and Germany up to totals recorded in the ir NIPA statistics (see bottom row in Table 1). In contrast, transfer incomes are reasonably well reported by Finnish and British respondents in the LIS household surveys. Obviously, the adjustment of U.S. transfer incomes is much smaller when the LIS measure of transfers includes Medicare and Medicaid payments as well as other cash and near-cash transfers. Thus, the lines labeled "USA (2)" in the top and bottom panels are much closer to one another than the lines labeled "USA."

Although the income adjustments have significant effects on our estimates of the age profile of transfer generosity, a couple of conclusions about the age profile seem valid regardless of whether the adjusted or unadjusted income estimates are used. First, the United States offers less generous benefits than Finland or Germany at every age. This implies that the tax on factor 
income needed to support transfers will be higher in Finland and Germany than in the United States, irrespective of the demographic profile of the population. So long as the countries have the same population age structure, the tax burden of supporting paygo transfers will be higher in Finland and Germany than it is in the United States, and this will be true whether the average age of the population is 35,55 , or 75 . Second, the age profile of public transfers is more heavily tilted toward the aged in Germany than it is in Finland. Similarly, public transfers are also more heavily tilted toward the aged in the United States than they are in the United Kingdom. British transfers to working-age adults are relatively more generous than are equivalent transfers in the United States, and the increase in benefit generosity after adults reach age 65 is relatively greater in the United States than it is in Britain. These differences in the age pattern of benefit generosity imply that a shift in the age structure toward an older population will cause a proportionately faster increase in the dependency burden in Germany compared with Finland and in the United States compared with the United Kingdom.

\section{The dependency burden of an aging population}

The results in the previous two sections can be combined to derive estimates of the tax on factor income needed to support paygo transfers. The calculations can be performed based on the current population age structure or on the predicted age structure at some future time. As a starting point it is informative to compare tax burdens when countries are assumed to share a common population age structure. This kind of comparison eliminates differences in measured tax burdens caused by the fact that the age distribution of the population differs across countries. To perform the required calculations, I have computed the unweighted average population age structure of Finland, Germany, the United Kingdom, and the United States using the population weights reported in the 1999-2000 LIS data files. Table 2 shows the results of these calculations when estimates of factor and transfer incomes are based on the unadjusted income reports in the LIS files. For the United States, this procedure yields two sets of estimates of government transfer income, one that includes only the cash and near-cash transfer incomes reported in the LIS files and a second that also includes U.S. Census Bureau imputations of the value of public health insurance transfers.

Table 2 shows the age distribution of factor income, transfer income, LIS-reported tax payments, and net disposable income when the population is divided into four age groups young adults (ages 15-34), the middle-aged (ages 35-54), the near-aged (ages 55-64), and the 
elderly (ages 65 and older). Estimates of average income and tax payments in a particular age group are measured relative to the average factor income received by a middle-aged person, that is, someone between ages 35 and 54. (The average factor income received by people between 35 and 54 is always equal to 100, by definition.) The estimates of factor income reported in Table 2 confirm the results displayed in Figures $4-6$. Aged adults in Britain and the United States receive substantially higher factor incomes than their counterparts in Finland and Germany. The income advantage of aged Britons relative to Finns and Germans is entirely due to higher capital income, while that of older Americans is due to both higher capital income and higher labor income. Among near-aged adults, Americans earn significantly higher factor incomes than their counterparts in all three European countries. Most of their income advantage reflects the fact that Americans between 55 and 64 receive much more labor income. This is mainly the result of higher employment rates among America's near-aged. The LIS survey files show that 54 percent of Americans between ages 60 and 64 derive income from working. The comparable employment rates in Finland, Germany, and the United Kingdom are 29 percent, 36 percent, and 31 percent, respectively.

The results in Table 2 also confirm the sizeable role of paygo government transfers as an income source in Finland and Germany as compared with the United Kingdom and the United States. As noted above, the difference between Britain and the other two European countries is comparatively small for adults under age 55, but it is sizeable for the aged and near-aged.

Britons older than 54 can expect to receive significantly smaller government transfers than their counterparts in Finland or Germany. Young, middle-aged, and near-aged adults in the United States receive very small transfers, but the relative position of America's aged depends crucially on whether government transfers in the form of health insurance benefits are included in the totals. If estimated U.S. Medicare and Medicaid payments are included, government transfers to the aged are relatively more costly in the United States than they are in Britain; if such transfers are excluded, transfers to the aged are lower in the United States than in Britain.

The LIS data files contain information on the income taxes and social insurance contributions that income recipients pay out of their gross incomes. The average withholdings for income taxes and employee social contributions are reported in Table 2. Bear in mind that these tax payments finance government spending for functions in addition to public transfers, including education, law enforcement, national defense, and interest on the public debt. The LIS 
tax estimates show, not surprisingly, that tax payments are highest for middle-aged adults and lowest for the aged. In all four countries, estimated tax withholdings are considerably higher for young adults than they are for the aged, notwithstanding the fact that the aged receive higher gross incomes than the young. Much of the income received by the elderly consists of lightly taxed transfers, while a much higher percentage of income received by the young is heavily taxed labor income. ${ }^{9}$ The LIS information on tax withholdings permits us to calculate average disposable income, that is, gross factor income and government transfers minus tax payments. Interestingly, when net income is expressed relative to the average factor income earned by 35 54 year-olds, aged and near-aged adults in all four countries receive similar disposable incomes, though the composition of income differs significantly across countries. The tabulations in Table 2 suggest that average citizens 65 and older receive disposable incomes that are 54 percent to 58 percent of the average factor incomes received by adults between 35 and 54. In Britain and the United States, a much larger percentage of disposable income received by the aged and nearaged is derived from factor income, while in Finland and Germany a much larger fraction is received as government transfers. In Germany and Britain, the aged also pay very low taxes.

The information about factor income and government transfers can be combined to calculate the tax rate on factor income needed to pay for transfers. When a common population age structure is assumed for the four countries, the implied tax rates are 30.7 percent in Finland, 25.8 percent in Germany, and 18.7 percent in the United Kingdom. The U.S. tax rate is 9.8 percent if included transfers are restricted to cash and near-cash transfer payments reported in the LIS file. The tax rate is 14.3 percent if U.S. transfers also include the Census Bureau imputations of Medicare and Medicaid payments.

Adjustments for income under-reporting. Alternative income and tax estimates are displayed in Table 3. These estimates reflect the income and tax adjustments to LIS data that are needed to reproduce NIPA estimates of aggregate factor and transfer income and of total personal income tax and social insurance contributions. These tabulations reflect higher estimates of earned income, paygo transfers, and tax withholdings for personal income taxes and

\footnotetext{
${ }^{9}$ In fact, the estimates in Table 2 understate the relative tax burdens borne by the young and middleaged, since they exclude the social insurance contributions made by employers in behalf of their workers. Recall that gross wage and salary income reported in the LIS files reflects the gross wages paid to workers rather than the total compensation paid by employers, including mandatory contributions for social insurance.
} 
employer and employee contributions for social insurance. For all four countries, the income adjustments yield an upward revision in the relative incomes received by the aged. Income sources that are particularly important to the aged and near-aged, including capital income and public transfers, suffer from worse under-reporting than labor earnings, which is relatively more important to the young and middle-aged. In at least one case, the upward adjustment is startlingly large. If the adjusted income tabulations are accepted at face value, the net incomes of the German aged and near-aged populations are higher than those of Germans between 35 and 54. Large adjustments in the incomes of the German elderly are needed to compensate for very large shortfalls in LIS income reports covering capital and transfer incomes.

Adjustments to compensate for income under-reporting do not necessarily have a large impact on estimates of the tax rates needed to support paygo transfers. The implied tax rate for Finland is essentially the same whether unadjusted or adjusted LIS data are used (30.7 percent in Table 2 versus 29.7 percent in Table 3). Since under-reporting of Finnish factor income is proportionately similar to under-reporting of transfer income, it makes little difference whether unadjusted or adjusted data are used to calculate the required tax rate. In Germany, on the other hand, under-reporting of transfer income is proportionately larger than under-reporting of factor income. Therefore, after an under-reporting adjustment is made, the implied tax rate needed to support German transfers increases. In Britain, income under-reporting is relatively more important for factor income than for transfer income, so the estimated tax rate to support government transfers falls when an under-reporting adjustment is made. The adjustment for income under-reporting in the United States yields estimates of the tax rate that are similar to the rate calculated in Table 2 when imputed Medicare and Medicaid benefit payments are included in the total of government transfers.

When we use a standardized population age profile to calculate the tax on factor income needed to pay for paygo transfers, the tax rate is highest in Finland and lowest in the United States (see Table 4). Using adjusted rather than unadjusted incomes to calculate the tax rate has some effect on results, but it has no impact on the rank order of tax rates in the four countries. The tax rates needed to pay for Finnish and German transfers are roughly twice the tax needed to pay for U.S. transfers. The required Finnish and German tax rates are approximately two-thirds higher than the rate needed for the United Kingdom. 
Table 4. Tax Rates Needed to Support Paygo Transfers in Four Countries, 1999-2000

Percent of factor income

\begin{tabular}{lccccc}
\hline & Finland & Germany & U.K. & U.S.A. & U.S.A. (2) \\
\hline \hline Implied by unadjusted LIS income & 30.7 & 25.8 & 18.7 & 9.8 & 14.3 \\
Implied by adjusted LIS income & 29.7 & 28.1 & 16.6 & 13.7 & 13.8 \\
\hline
\end{tabular}

Sources: See Tables 2 and 3.

To see how these tax rates will be affected by anticipated population aging, we can derive estimates of $t$ using forecasts of the future age distribution of national populations. The estimates displayed in Figures 8 and 9 are based on population projections of the U.S. Census Bureau (2004). The estimated tax rates in Figure 8 use a standardized population age profile for the four countries. That is, each of the countries is assumed to have an identical age structure in future years, where the age structure in a given year is the unweighted average of the population age profile for that year predicted by the Census Bureau. The estimates of $t$ in Figure 8 thus eliminate the effects of differential population aging in the four countries and highlight the influence of national differences in the age distribution of factor incomes and the age pattern of transfer payment generosity. Predicted tax rates are estimated using estimates of $f_{i}$ and $\beta_{i}$ derived from income reports that have been adjusted for income under-reporting. In other words, the estimates are based on data in the lower panels rather than the top panels of Figures 6 and $7 .{ }^{10}$ It seems reasonable to think the results that adjust for income under-reporting are preferable to estimates that rely solely on the unadjusted income reports in the LIS files.

Figure 8 shows plainly the importance of cross-national differences in the age distribution of factor incomes and transfer benefits. Finland and Germany face much higher taxes to support paygo transfers than Britain and the United States. Because the age pattern of benefit generosity is more heavily tilted towards the aged in Germany, the tax rate rises proportionately faster in that country than it does in the other three. Note that the German tax rate is initially lower than the Finnish rate in 2000 but rises more steeply over the next half century. By 2050 the predicted German tax rate is 3 percentage points higher than the rate in Finland.

${ }^{10}$ The predictions of $\mathrm{t}$ for the United States are based on estimates of $\beta_{i}$ labeled "USA" rather than "USA (2)" in the lower panel of Figure 7. The predic ted U.S. tax rate would be slightly higher and rise somewhat faster if the estimates labeled "USA (2)" were used instead. 
Figure 9 shows predicted tax burdens between 2000 and 2050 based on the Census Bureau's forecasts of the likely age structure of each country. Since the U.K. population is older than the U.S. population and growing older more rapidly, the difference between U.K. and U.S. tax rates is both larger and faster growing in Figure 9 than it is in Figure 8. Similarly, the German population is expected to age faster than the population of Finland, reinforcing the effects of a paygo transfer system that is heavily tilted in favor of Germany's elderly. By the year 2050, the tax-rate difference between Germany and Finland is 6.4 percentage points. The differing rates of population aging tend to magnify the tax rate differences in the four countries.

Results for the four countries are summarized in Table 5. Two sets of estimated tax rates are shown for each country. The rates listed in the columns labeled "a" are the paygo tax rates a country would face if its population age structure in each indicated year is the unweighted average age structure of all four countries. The rates listed in columns labeled " $b$ " are the tax rates countries will face given the national population age structure predicted by the Census Bureau for the indicated year. By comparing the tax rates in the "a" columns for the four countries, we can see which countries have the most burdensome transfer systems and which have an age distribution of factor incomes and paygo transfers that is particularly sensitive to population aging. As should be obvious from the discussion so far, Finland and Germany have the most burdensome benefit systems, but Germany and the United States have a combination of $f_{i}$ and $\beta_{i}$ that makes their tax burdens more highly sensitive to increases in the average population age. Assuming a common age structure and common trend toward population aging, $\mathrm{t}$ would rise 46 percent in Finland and 45 percent in the United Kingdom between 2000 and 2050, but it would increase 55 percent in the United States and 64 percent in Germany. The faster increase in taxes in Germany and the United States is mainly the result of a public transfer system that is more heavily tilted toward the aged. That is, the gap between transfer benefits received by the aged, on the one hand, and the non-aged on the other, is proportionately bigger in Germany and the United States than it is in Finland or the United Kingdom. The tilt in the U.S. benefit structure is large enough to offset an age profile of factor income that is also unusually tilted toward the aged. Compared with their counterparts in the other three countries, Americans older than 55 receive unusually large factor incomes. This means factor income will fall more gradually in the United States than in Finland or the United Kingdom when the population grows 
older. Nonetheless, the tax needed to support paygo transfers will rise proportionately faster in the United States than in either Finland or Britain.

The Table 5 entries under columns labeled "b" show the trend in tax rates required to support paygo transfers based on each country's predicted population change. In spite of a paygo benefit structure that is tilted toward the aged, the United States is predicted to see the smallest proportional rise in tax burdens. Between 2000 and 2050, $\mathrm{t}$ will rise just 41 percent in the United States compared with 45 percent in Finland, 57 percent in the United Kingdom, and 63 percent in Germany. The main reason for the faster rise in Finnish and U.K. tax rates is the faster aging of their populations compared with that of the United States. The German tax rate will rise faster than the U.S. rate because of faster population aging and because the age distribution of factor incomes and transfer benefits in Germany makes the tax rate more sensitive to a shift in the population age structure.

\section{Conclusions and extensions}

While all industrial countries will grow older over the next half century, the burden of providing public support to their aging populations will not rise by the same fraction. One reason is that their populations will grow older at different rates. Countries with comparatively high fertility and immigration, such as the United States, will see a slower shift in the age structure compared with countries where fertility rates are lower and immigration is less common. Even ignoring the effect of differences in the pace of population aging, industrial countries would experience widely varying burdens as a result of population aging. This paper has highlighted the role of differences in the age structure of factor incomes and of transfer payment generosity in determining the future burden of public support for the aged. The elderly and near-elderly in some countries earn comfortable incomes from their own labor and investments. In other countries, the aged receive much smaller factor incomes, and they depend more heavily on transfer payments from the government. The age profiles of factor income and of transfer payment generosity taken in combination determine the taxes that citizens must pay out of their capital and labor incomes to support transfer recipients.

Using income reports in the LIS files it is straightforward to measure the age profiles of factor incomes and paygo benefit payments in a number of industrialized countries. These estimates can be matched up to aggregate incomes reported in national income and product accounts to verify the plausibility of the income reports obtained in household surveys. The 
conclusions drawn in this paper are broadly consistent whether we use uncorrected micro-census income reports or reports adjusted to reflect income under-reporting in the LIS files. A couple of conclusions are unsurprising. Generous social welfare states in continental Europe offer more costly and burdensome paygo transfers to their aged citizens than comparable benefits provided by the United Kingdom or the United States. The generous package of benefits offered in continental Europe will require heavier taxes on factor incomes than are needed in the Englishspeaking count ries regardless of the age structure of the national population. At the same time, factor incomes in continental Europe tend to fall off much more rapidly in late middle age than is the case in either Britain or the United States, in part because labor incomes decline faster after age 55 than they do in the United States and in part because capital incomes are significantly smaller than they are in both Britain and the United States. This pattern of factor income payments will mean that the future availability of factor income will fall off faster in Continental Europe than in the English-speaking countries as the population grows older.

The estimates reported in this paper show, however, that population aging will have a relatively bigger impact in countries where the age profile of benefits is more heavily tilted in favor of the elderly. Countries with relatively low overall generosity in social welfare, such as the United States, may nonetheless have benefit systems that are steeply tilted in favor of the aged. High-generosity systems, including the one offered in Finland, may offer public benefits that are less favorably structured in behalf of the elderly. Among the countries considered here, Germany and the United States have social insurance and assistance systems that provide relatively generous benefits to the aged and less generous transfers to the non-aged. Even though average paygo transfers rise with a person's age in Finland and the United Kingdom, the schedule of benefits is less steeply sloped than it is in Germany or the United States. If all four countries shared the same age structure and faced an identical increase in average population age, the tax rate needed to support transfers would climb more slowly in Finland and Britain than in Germany or the United States. This result is mainly due to the difference in the age profile of benefits offered by the four countries.

Two extensions of the study could improve our understanding of future dependency burdens. First, the current analysis is based on very imperfect measures of the incomes received by aged and non-aged citizens from public health insurance. Of the four countries included in the study, only one - the United States - provides information on the value to individual 
households of public medical insurance. The results in Figure 7 suggest that the inclusion of these benefits has an important effect on the estimated age profile of paygo transfers. If such transfers could be taken into account for all countries in the study, it is conceivable some of the results would change. Moreover, the health insurance imputations for the United States have important shortcomings. The Census Bureau imputes the value of public health insurance to American households using a very simple algorithm. The imputation procedure does not account for the rising cost of health insurance for people past the age of 65 . Recent estimates by Louise Sheiner show that average Medicare spending by Americans between 75 and 79 is about 50 percent higher than average spending by 65-69 year-olds. Per-person spending by people 85 and older is more than twice as high as the average amount spent by 65-69 year-olds (Sheiner, 2004, Figure 2). The U.S. Census Bureau estimates of the value of Medicare insurance do not fully reflect the rising age profile of insurance outlays. The age profile of public health insurance spending should be explicitly reflected in future estimates of transfers and their associated tax cost.

My estimates of future tax burdens are based on the assumption that the current age profiles of factor incomes and transfer benefits will remain unchanged in the future. Although this assumption provides a sensible starting point for comparing countries and transfer systems, it is not very credible in the long run. The estimates in Figure 7 imply that the tax on German factor incomes needed to support paygo transfers could approach 50 percent within the next half century. The actual tax burden to support all state spending would be higher than this, because taxpayers will also need to pay for public schools, national defense, and other government obligations. The age profile of factor incomes and paygo transfers will probably change long before German tax rates reach the level implied by these calculations. Public pensions will be scaled back or delayed, and workers will be encouraged to accumulate more savings to help pay for their own retirement. Of course, some trends may lift the tax rates needed to support paygo transfers. In a number of countries, including the United States, expenditures on medical care are rising faster than spending on other kinds of household consumption. Since much of this spending, especially by the elderly, is financed out of public budgets, it is possible that the future age profile of transfer benefits will become even more tilted in favor of the aged. By investigating historical evidence about the age distribution of factor incomes and transfer 
payments, we may gain some understanding of the economic and political determinants of the tax burden. 


\section{References}

Bosworth, Barry P., and Gary Burtless. 1998. "Population Aging and Economic Performance." In Aging Societies: The Global Dimension, Barry P. Bosworth and Gary Burtless, eds. Washington: The Brookings Institution.

Bosworth, Barry P., and Gary Burtless. 2004. "Pension Reform and Saving," National Tax Journal 57(3), September 2004, pp. 703-26

Burtless, Gary. 2001. "The Rationale for Fundamental Pension Reform in Germany and the United States: An Assessment," ifo Studien, Vol 47, no. 2.

Burtless, Gary. 2002. “Does Population Aging Represent a Crisis for Rich Societies?”Working paper prepared for the annual meetings of the American Economic Association. Washington: The Brookings Institution.

Burtless, Gary. 2003. "What Do We Know about the Risk of Individual Account Pensions? Evidence from Industrial Countries." American Economic Review, Papers and Proceedings (May).

Casey, Bernard H., and AtsuhiroYamada. 2003. "The Public-Private Mix of Retirement Income in Nine OECD Countries: Some Evidence from Micro Data and an Exploration of Its Implications." In Rethinking the Welfare State: The Political Economy of Pension Reform, M. Rein and W. Schmäl, eds. Cheltenham: Edward Elgar.

Cutler, David M., James M. Poterba, Louise M. Sheiner, and Lawrence H. Summers. 1990. "An Aging Society: Opportunity or Challenge?" Brookings Papers on Economic Activity (Spring), 1-73.

Cutler, David M., and Louise M. Sheiner. 2001. "Demographics and Medical Care Spending: Standard and Non-Standard Effects." In Demographic Change and Fiscal Policy, A. Auerbach and R. Lee, eds. Cambridge: Cambridge University Press.

de Serres, Alain, and Florian Pelgrin. 2002. "The Decline in Private Saving Rates in the 1990s in OECD Countries: How Much Can Be Explained by Non-wealth Factors?" Economics Department Working Paper No. 344. Paris: OECD

Disney, Richard, and Edward Whitehouse. 2002. "The Economic Well-Being of Older People in International Perspective: A Critical Review.” LIS Working Paper No. 306.

Luxembourg: Luxembourg Income Study.

Marquis, Milt. 2002. "What's Behind the Low U.S. Personal Saving Rate?" FRBSF Economic Letter No. 2002-09. San Francisco: Federal Reserve Bank of San Francisco.

OASDI Trustees. 2004. The 2004 Annual Report of the Board of Trustees of the Federal OldAge and Survivors Insurance and Disability Insurance Trust Funds. Washington:

OASDI Trustees. 
OECD. 2004. OECD Health Data 2004. Paris: OECD.

Rein, Martin, and Heinz Stapf-Finé. 2001. "Income Packaging and Economic Well-Being at the Last Stage of the Working Career." LIS Working Paper No. 270. Luxembourg: Luxembourg Income Study.

Sheiner, Louise. 2004. "The Effects of Technology on the Age Distribution of Health Spending: A Cross-Country Perspective." Working Paper. Washington: Board of Governors of the Federal Reserve System.

U.S. Census Bureau. 2004. International Data Base < http://www.census.gov/ipc/www/idbnew.html>. Downloaded July 1, 2004. Washington: U.S. Census Bureau.

Verrinder, John. 2002. "Saving Rates in Europe." Statistics in Focus No. 33/2002. Brussels: Eurostat. 


\section{Table 1. Aggregate Incomes Reported in LIS Data Files and in National Income and Product Accounts, 1999-2000}

\begin{tabular}{|c|c|c|c|c|}
\hline & $\begin{array}{c}\text { Finland } \\
\text { Bil. Euros } \\
(2000) \\
\end{array}$ & $\begin{array}{c}\text { Germany } \\
\text { Bil. Euros } \\
(2000) \\
\end{array}$ & $\begin{array}{c}\text { United } \\
\text { Kingdom } \\
\text { Bil. Pounds } \\
(1999) \\
\end{array}$ & $\begin{array}{c}\text { United } \\
\text { States } \\
\text { Bil. Dollars } \\
(2000) \\
\end{array}$ \\
\hline (1) Gross wage and salary income (LIS) & 48.8 & 839.4 & 377.0 & $4,701.5$ \\
\hline (2) Employee compensation (NIPA) & 62.8 & $1,099.1$ & 495.8 & $5,782.7$ \\
\hline (3) Self-employment income (LIS) & 5.1 & 122.5 & 53.1 & 345.2 \\
\hline (4) Surplus of unincorporated businesses owned by households (NIPA) & 5.3 & 231.4 & 54.2 & 728.4 \\
\hline (5) Income derived from capital, including funded pensions (LIS) & 6.3 & 60.0 & 60.8 & 583.9 \\
\hline (6) Property income, receivable (NIPA) & 7.8 & 309.0 & 119.0 & $1,461.6$ \\
\hline (7) Imputed income from owner-occupied homes (LIS) /a/ & 5.0 & 43.8 & 53.1 & 459.9 \\
\hline (8) Government transfers, except funded pensions (LIS) & 19.6 & 312.4 & 102.8 & 533.6 \\
\hline (9) Social benefits, receivable (NIPA) & 23.5 & 532.7 & 120.8 & $1,044.1$ \\
\hline \multicolumn{5}{|l|}{ Income recorded on LIS as a percentage of amount in NIPA: } \\
\hline Wage and salary compensation: Row (1)/Row (2) & 78 & 76 & 76 & 81 \\
\hline Self-employment income: Row (3)/Row (4) & 96 & 53 & 98 & 47 \\
\hline Capital income: Row (5)/Row (6) & 81 & 19 & 51 & 40 \\
\hline Total factor income: $[\operatorname{Rows}(1)+(3)+(5)+(7)] /[\operatorname{Rows}(2)+(4)+(6)]$ & 86 & 65 & 81 & 76 \\
\hline Government transfers or social benefits: Row (8) / Row (9) & 83 & 59 & 85 & 51 \\
\hline
\end{tabular}

Source: Author's tabulations of LIS data files and OECD and U.S. estimates of national income and products accounts.

/a/ Ignores cost of property taxes. U.K. estimates derived from author's tabulations of 1999 British Household Panel Survey. 
Table 2. Gross and Net Incomes by Age Group in Four Countries: Estimates Based on Unadjusted LIS Income Reports

Percent of average factor income received by 35-54 year-olds

\begin{tabular}{|c|c|c|c|c|c|}
\hline & \multicolumn{5}{|c|}{ Age group } \\
\hline & $15-34$ & $35-54$ & $55-64$ & $65-94$ & 15-94 \\
\hline \multicolumn{6}{|l|}{ Finland (2000) } \\
\hline Factor income & 49 & 100 & 66 & 20 & 65 \\
\hline of which -- Labor & 47 & 87 & 48 & 3 & 53 \\
\hline Capital & 2 & 13 & 18 & 18 & 11 \\
\hline Transfer income & 10 & 13 & 29 & 45 & 20 \\
\hline Taxes & -15 & -32 & -25 & -11 & -22 \\
\hline Net disposable income & 44 & 81 & 70 & 54 & 63 \\
\hline \multicolumn{4}{|c|}{ Memo: Implied tax on Finland factor income for Paygo transfers } & \multicolumn{2}{|c|}{$30.7 \%$} \\
\hline \multicolumn{6}{|l|}{ Germany (2000) } \\
\hline Factor income & 44 & 100 & 66 & 13 & 62 \\
\hline of which -- Labor & 43 & 94 & 57 & 3 & 56 \\
\hline Capital & 1 & 6 & 9 & 10 & 6 \\
\hline Transfer income & 4 & 8 & 20 & 49 & 16 \\
\hline Taxes & -15 & -34 & -21 & -4 & -21 \\
\hline Net disposable income & 34 & 74 & 66 & 58 & 57 \\
\hline \multicolumn{4}{|c|}{ Memo: Implied tax on German factor income for Paygo transfers } & \multicolumn{2}{|c|}{$25.8 \%$} \\
\hline \multicolumn{6}{|l|}{ United Kingdom (1999) } \\
\hline Factor income & 56 & 100 & 71 & 32 & 70 \\
\hline of which -- Labor & 53 & 88 & 43 & 2 & 55 \\
\hline Capital & 2 & 12 & 29 & 30 & 14 \\
\hline Transfer income & 7 & 10 & 13 & 30 & 13 \\
\hline Taxes & -13 & -22 & -15 & -5 & -15 \\
\hline Net disposable income & 50 & 87 & 69 & 57 & 67 \\
\hline \multicolumn{4}{|c|}{ Memo: Implied tax on U.K. factor income for Paygo transfers } & \multicolumn{2}{|c|}{$18.7 \%$} \\
\hline \multicolumn{6}{|c|}{ United States, Excluding Public Health Insurance (2000) } \\
\hline Factor income & 47 & 100 & 86 & 40 & 70 \\
\hline of which -- Labor & 45 & 89 & 64 & 11 & 57 \\
\hline Capital & 3 & 11 & 23 & 29 & 13 \\
\hline Transfer income & 2 & 3 & 6 & 23 & 7 \\
\hline Taxes & -10 & -24 & -20 & -7 & -16 \\
\hline Net disposable income & 39 & 80 & 72 & 56 & 61 \\
\hline \multicolumn{4}{|c|}{ Memo: Implied tax on U.S. factor income for Paygo transfers } & \multicolumn{2}{|c|}{$9.8 \%$} \\
\hline \multicolumn{6}{|c|}{ United States, Including Imputed Public Health Insurance (2000) } \\
\hline Factor income & 47 & 100 & 86 & 40 & 70 \\
\hline of which -- Labor & 45 & 89 & 64 & 11 & 57 \\
\hline Capital & 3 & 11 & 23 & 29 & 13 \\
\hline Transfer income & 3 & 4 & 9 & 36 & 10 \\
\hline Taxes & -10 & -24 & -20 & -7 & -16 \\
\hline Net disposable income & 40 & 80 & 75 & 69 & 64 \\
\hline \multicolumn{4}{|c|}{ Memo: Implied tax on U.S. factor income for Paygo transfers } & & \\
\hline
\end{tabular}

Source: Author's tabulations of LIS data files as explained in the text. 
Table 3. Gross and Net Incomes by Age Group in Four Countries: Estimates Based on LIS Income Reports Adjusted to Reflect NIPA Income Totals

Percent of average factor income received by $35-54$ year-olds

\begin{tabular}{|c|c|c|c|c|c|}
\hline & \multicolumn{5}{|c|}{ Age group } \\
\hline & $15-34$ & $35-54$ & $55-64$ & $65-94$ & $15-94$ \\
\hline \multicolumn{6}{|l|}{ Finland (2000) } \\
\hline Factor income & 49 & 100 & 62 & 14 & 63 \\
\hline of which -- Labor & 47 & 87 & 47 & 2 & 53 \\
\hline Capital & 3 & 13 & 15 & 12 & 10 \\
\hline Transfer income & 9 & 12 & 28 & 42 & 19 \\
\hline Taxes & -22 & -45 & -31 & -9 & -29 \\
\hline Net disposable income & 36 & 67 & 59 & 47 & 53 \\
\hline \multicolumn{4}{|c|}{ Memo: Implied tax on Finland factor income for Paygo transfers } & \multicolumn{2}{|c|}{$29.7 \%$} \\
\hline \multicolumn{6}{|l|}{ Germany (2000) } \\
\hline Factor income & 41 & 100 & 72 & 23 & 63 \\
\hline of which -- Labor & 38 & 86 & 52 & 3 & 51 \\
\hline Capital & 3 & 14 & 20 & 20 & 12 \\
\hline Transfer income & 5 & 9 & 23 & 55 & 18 \\
\hline Taxes & -17 & -42 & -25 & -2 & -24 \\
\hline Net disposable income & 28 & 67 & 69 & 76 & 57 \\
\hline \multicolumn{4}{|c|}{ Memo: Implied tax on German factor income for Paygo transfers } & \multicolumn{2}{|c|}{$28.1 \%$} \\
\hline \multicolumn{6}{|l|}{ United Kingdom (1999) } \\
\hline Factor income & 55 & 100 & 69 & 29 & 69 \\
\hline of which -- Labor & 51 & 84 & 40 & 2 & 52 \\
\hline Capital & 4 & 16 & 29 & 27 & 16 \\
\hline Transfer income & 6 & 8 & 11 & 26 & 11 \\
\hline Taxes & -22 & -38 & -22 & -5 & -25 \\
\hline Net disposable income & 39 & 71 & 58 & 51 & 55 \\
\hline \multicolumn{4}{|c|}{ Memo: Implied tax on U.K. factor income for Paygo transfers } & \multicolumn{2}{|c|}{$16.6 \%$} \\
\hline \multicolumn{6}{|c|}{ United States, Excludi ng Public Health Insurance(2000) } \\
\hline Factor income & 45 & 100 & 89 & 46 & 71 \\
\hline of which -- Labor & 41 & 83 & 61 & 11 & 54 \\
\hline Capital & 4 & 17 & 28 & 35 & 17 \\
\hline Transfer income & 3 & 5 & 9 & 32 & 10 \\
\hline Taxes & -11 & -24 & -21 & -6 & -16 \\
\hline Net disposable income & 37 & 80 & 78 & 72 & 65 \\
\hline \multicolumn{4}{|c|}{ Memo: Implied tax on U.S. factor income for Paygo transfers } & \multicolumn{2}{|c|}{$13.7 \%$} \\
\hline \multicolumn{6}{|c|}{ United States, Including Imputed Public Health Insurance(2000) } \\
\hline Factor income & 45 & 100 & 89 & 46 & 71 \\
\hline of which -- Labor & 41 & 83 & 61 & 11 & 54 \\
\hline Capital & 4 & 17 & 28 & 35 & 17 \\
\hline Transfer income & 3 & 4 & 8 & 35 & 10 \\
\hline Taxes & -11 & -24 & -21 & -6 & -16 \\
\hline Net disposable income & 37 & 80 & 77 & 74 & 65 \\
\hline \multicolumn{4}{|c|}{ Мето: Implied tax on U.S. factor income for Paygo transfers } & 13. & \\
\hline
\end{tabular}

Source: Author's tabulations of LIS data files and OECD and U.S. estimates of national income and product account data as explained in the text.

Note: Age distribution of population is normalized using average population structure in the four countries. 
Table 4. Tax Rates Needed to Support Paygo Transfers in Four Countries, 1999-2000 Percent of factor income

\begin{tabular}{lccccc}
\hline & Finland & Germany & U.K. & U.S.A. & U.S.A. (2) \\
\hline \hline Implied by unadjusted LIS income & 30.7 & 25.8 & 18.7 & 9.8 & 14.3 \\
Implied by adjusted LIS income & 29.7 & 28.1 & 16.6 & 13.7 & 13.8 \\
\hline
\end{tabular}

Sources: See Tables 2 and 3.

Table 5. Effect of Population Aging on Tax Rate, t, Needed to Finance Paygo Transfers, 2000-2050

\begin{tabular}{|c|c|c|c|c|c|c|c|c|c|}
\hline & \multirow[b]{2}{*}{ Year } & \multicolumn{2}{|c|}{ Finland } & \multicolumn{2}{|c|}{ Germany } & \multicolumn{2}{|c|}{ United Kingdom } & \multicolumn{2}{|c|}{ United States } \\
\hline & & (a) & (b) & (a) & (b) & (a) & (b) & (a) & (b) \\
\hline & 2000 & 29 & 29 & 28 & 30 & 17 & 17 & 14 & 13 \\
\hline & 2010 & 32 & 34 & 31 & 33 & 18 & 19 & 15 & 13 \\
\hline & 2020 & 36 & 39 & 36 & 37 & 20 & 20 & 17 & 15 \\
\hline & 2030 & 41 & 41 & 42 & 44 & 22 & 23 & 19 & 17 \\
\hline & 2040 & 42 & 42 & 45 & 47 & 23 & 26 & 21 & 18 \\
\hline & 2050 & 43 & 42 & 46 & 49 & 24 & 27 & 21 & 18 \\
\hline$t$ in & $\begin{array}{l}\text { a percent } \\
t \text { in } 2000\end{array}$ & 146 & 145 & 164 & 163 & 145 & 157 & 155 & 141 \\
\hline
\end{tabular}

Source: Author's tabulations of LIS and NIPA data files as explained in text and population projections of the U.S. Census Bureau.

(a) The predicted age structure is assumed identical for each country and reflects the four-country average age structure.

(b) Estimated $t$ is based on the predicted age structure for the indicated country. 
Figure 1. Stylized Distribution of Factor Incomes and Paygo Benefits, by Age

Factor income of

35-54 year-olds $=100$

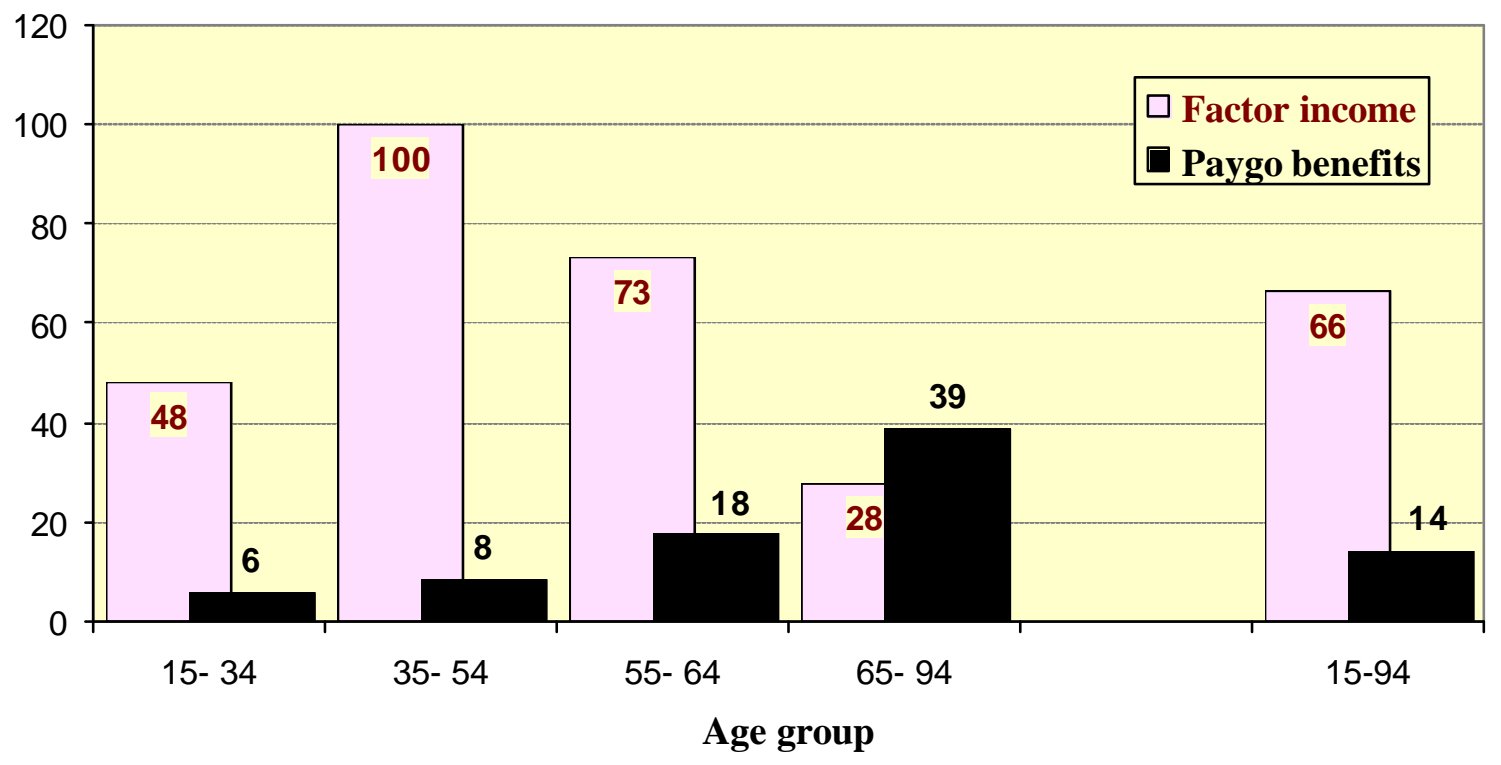

Figure 2. Impact of Population Aging on Tax Rate Needed to Finance Paygo

Transfers (Initial tax rate $=100$ )

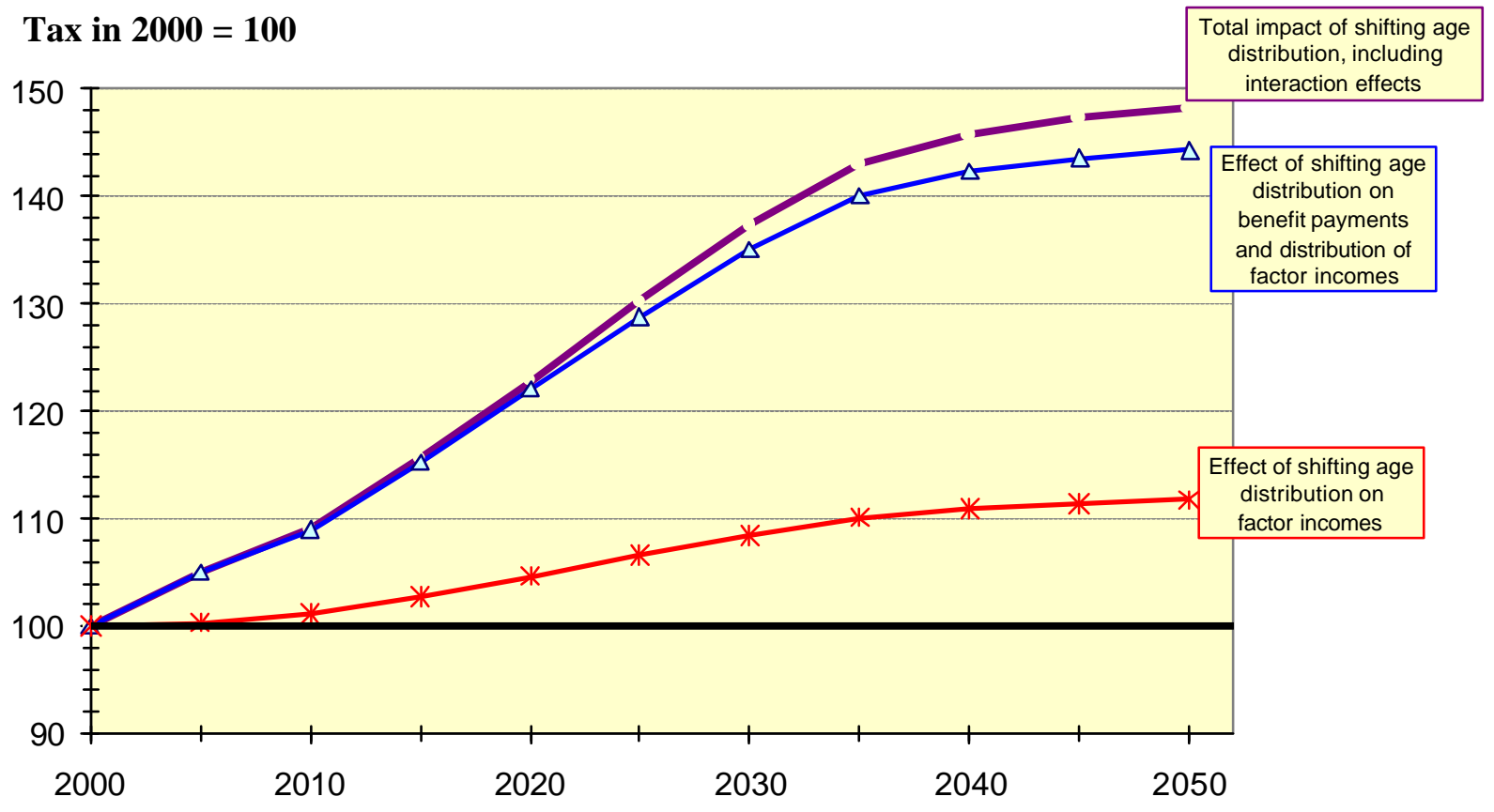

Source: Author's calculations as explained in text. 


\section{Figure 3. Old-age Dependency Ratio, 2000-2050}

Persons 65 and older per 100 persons age 15-64

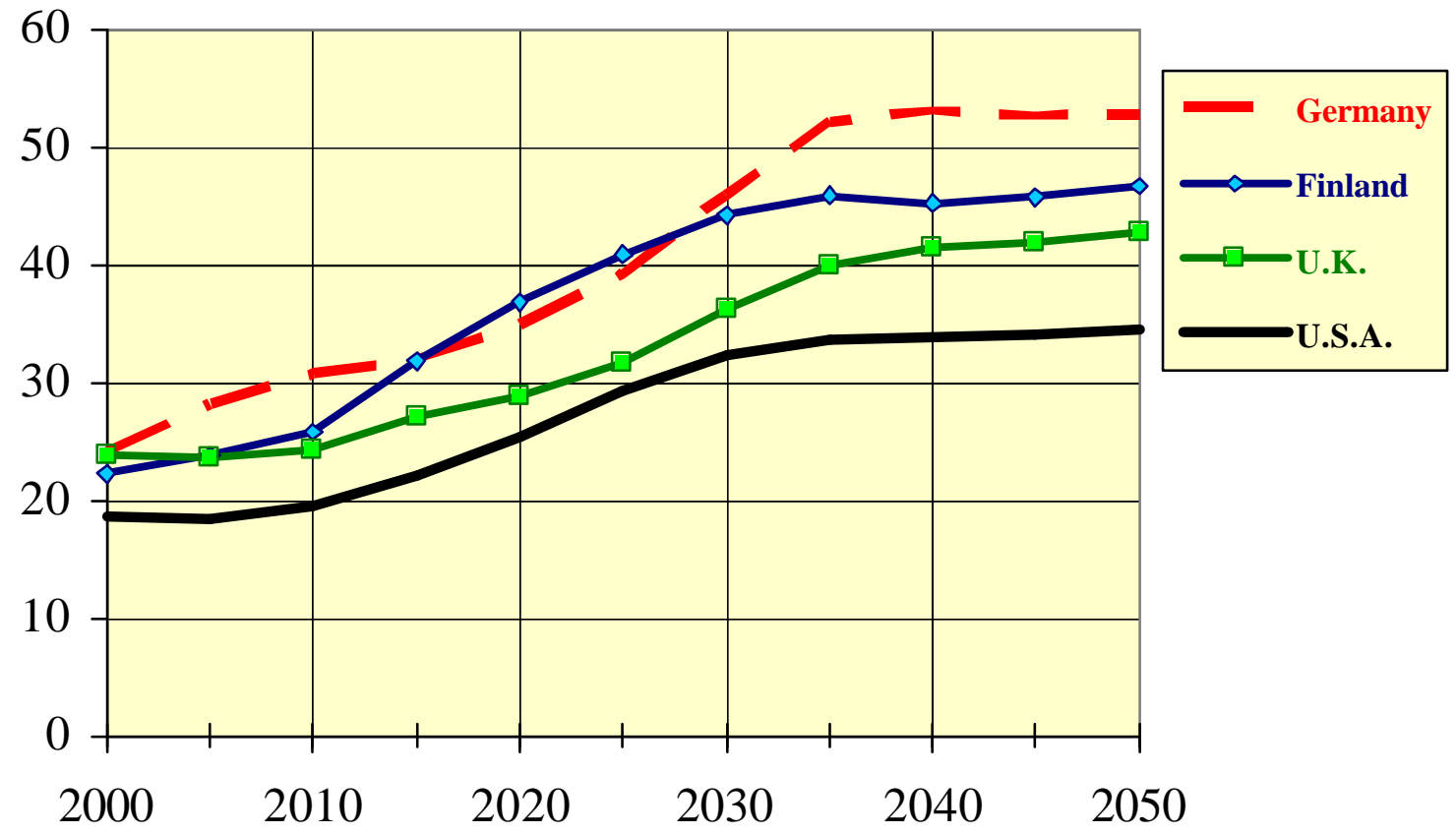

Source: Author's tabulations of U.S. Census Bureau population projections. 
Figure 4. Age Pattern of Factor Income in Four Countries, 1999-2000

Factor income received by average 45-49 year-old = 100

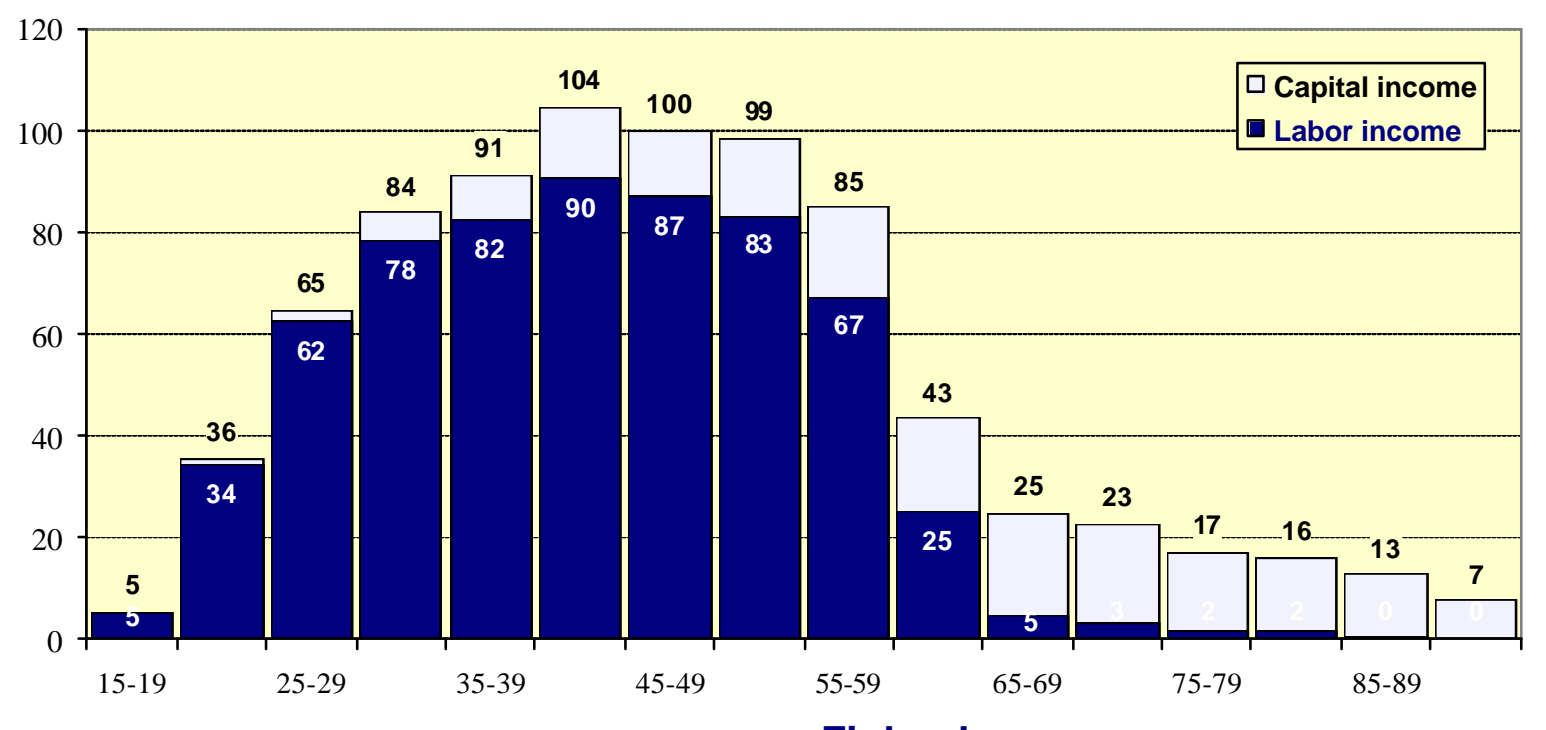

Age group: Finland

Factor income received by average 45-49 year-old = 100

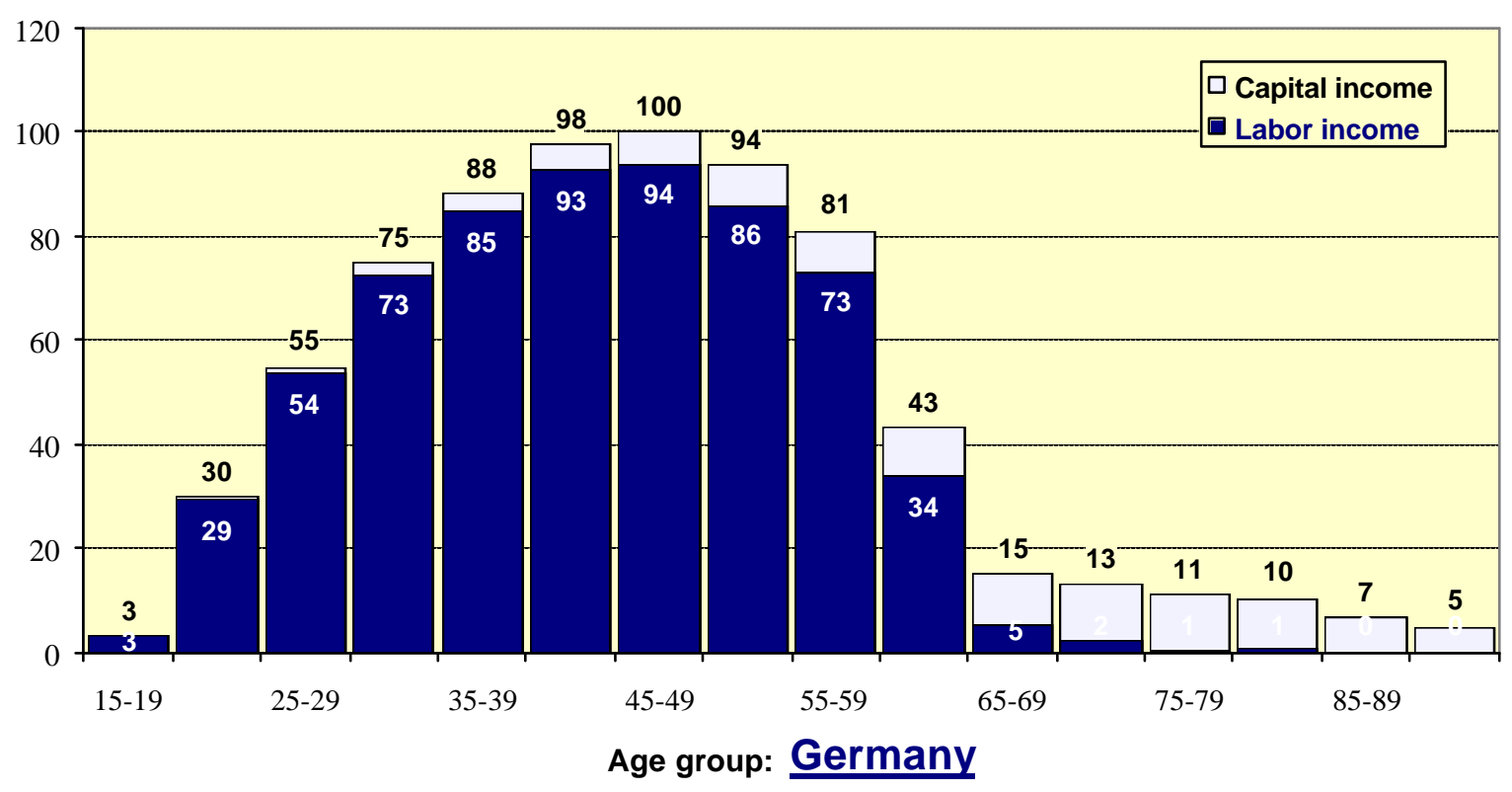

Source: Author's tabulations of LIS data files as explained in text. 
Figure 4. Age Pattern of Factor Income in Four Countries (continued)

Factor income received by average $45-49$ year-old $=100$

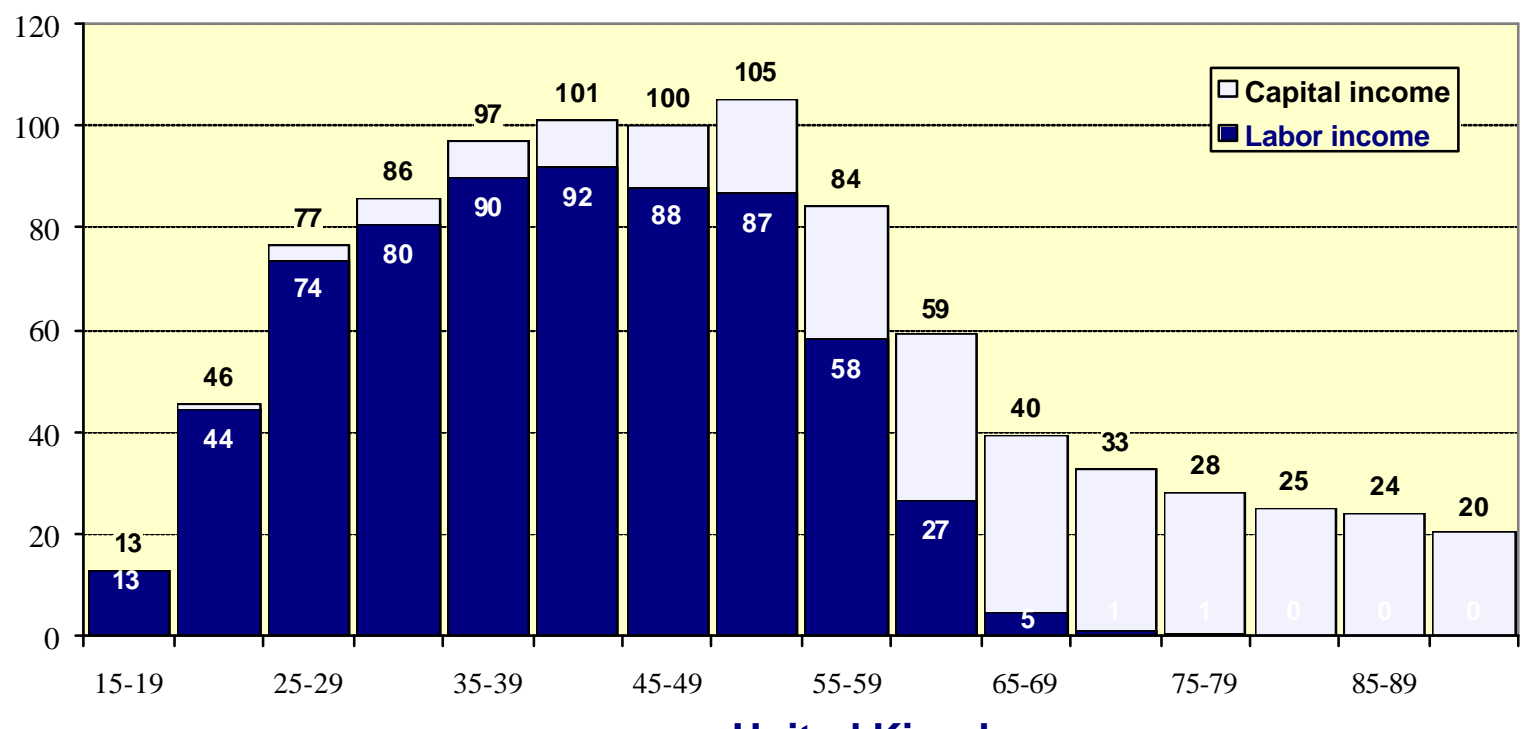

Age group: United Kingdom

Factor income received by average $45-49$ year-old $=100$

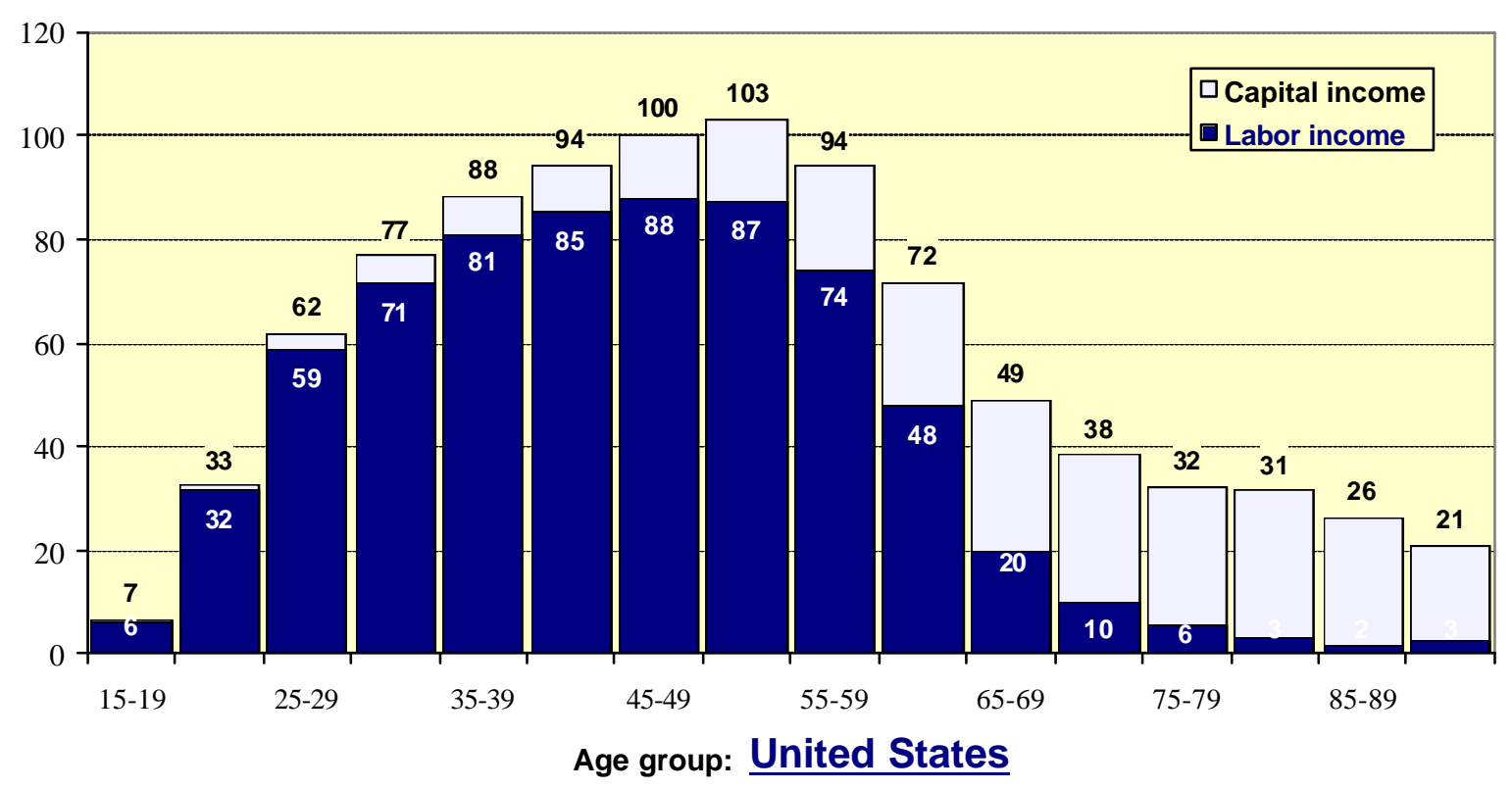

Source: Author's tabulations of LIS data files as explained in text. 


\section{Figure 5. Age Profiles of Labor and Capital Income in Four Countries, 1999-2000}

\section{Labor Income as \% of Average Labor}

Income Received by 45-49 Year-olds

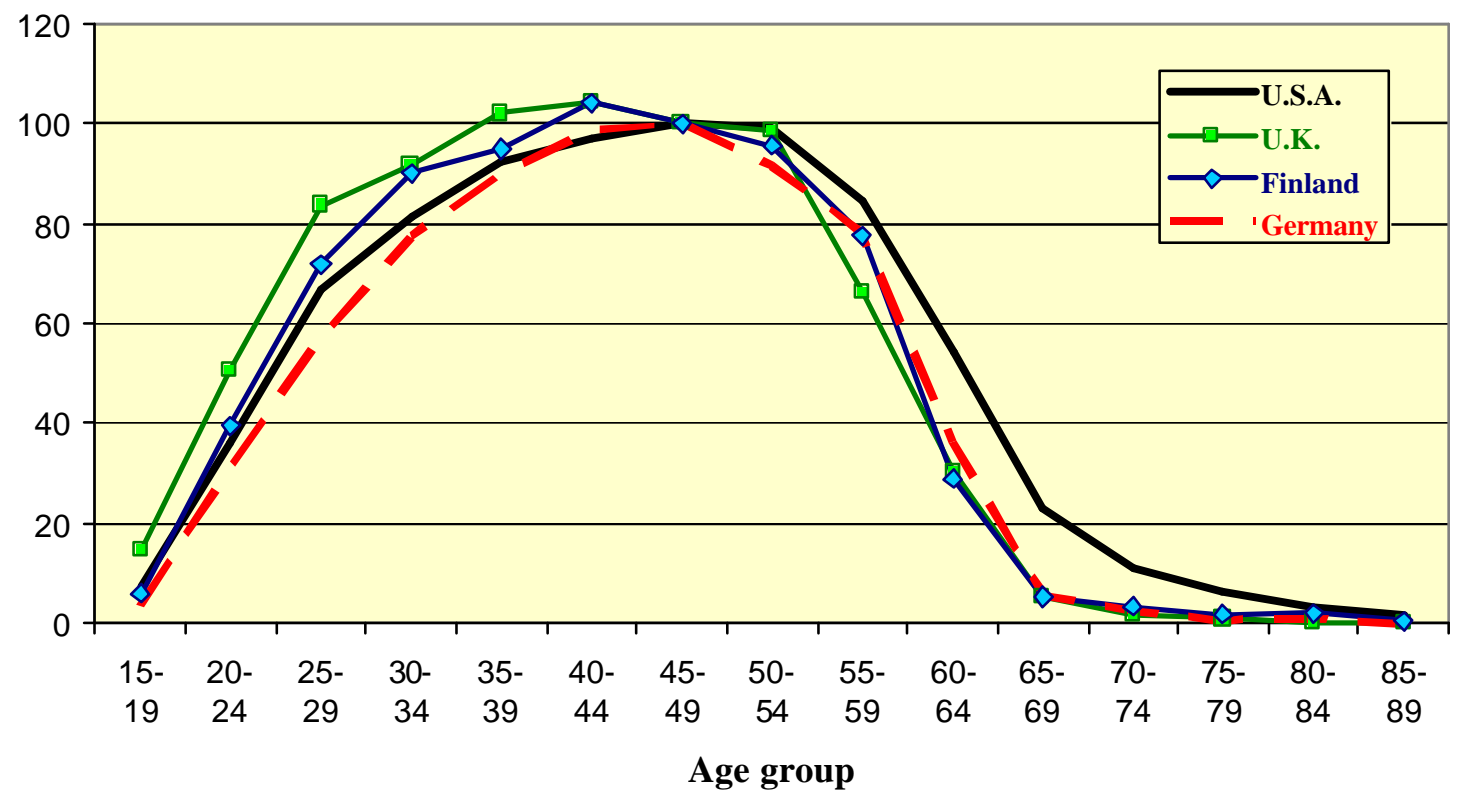

\section{Capital Income as \% of Average Capital} Income Received by 45-49 Year-olds

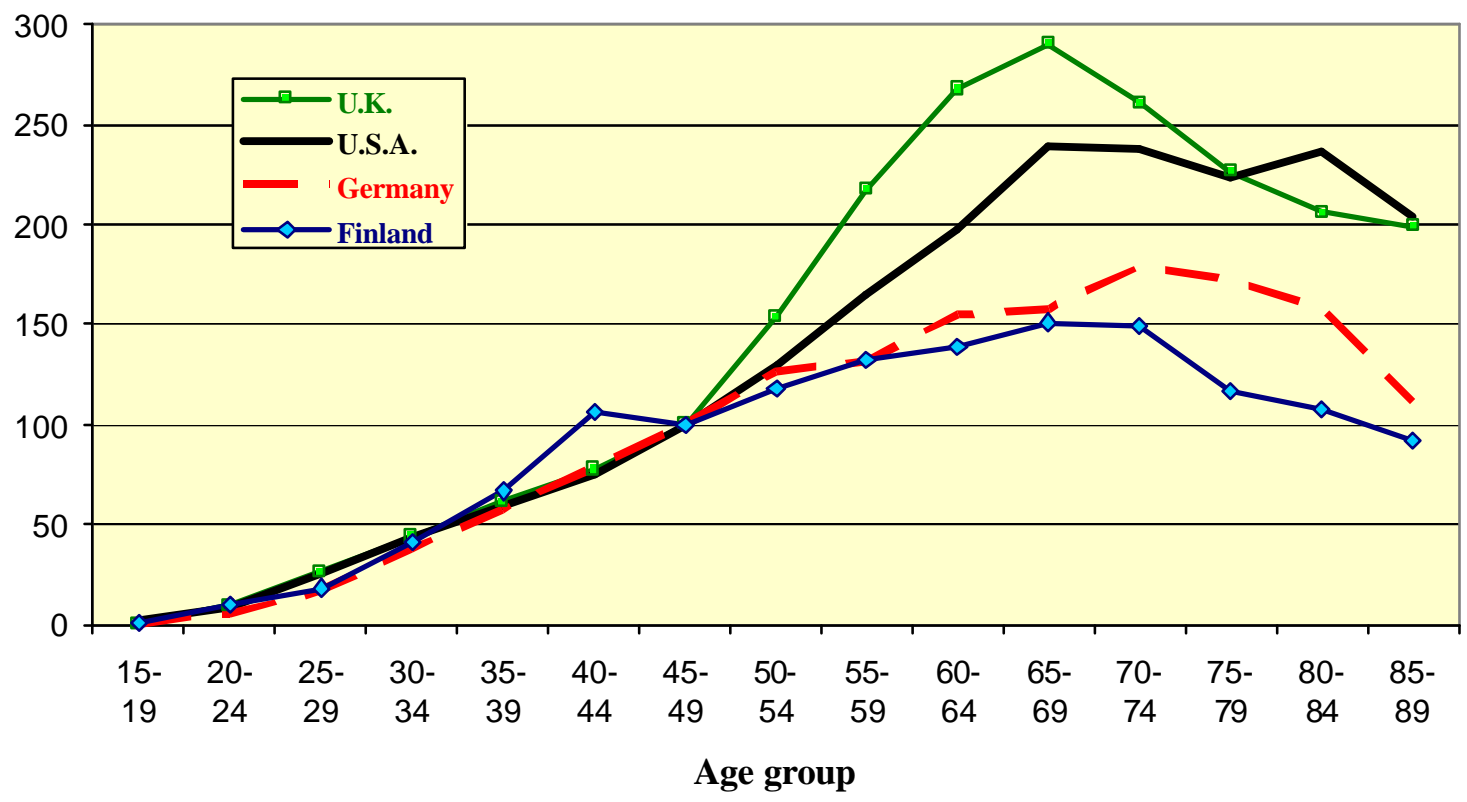

Source: Author's tabulations of LIS data files as explained in text. 
Figure 6. Age Profiles of Factor Income in Four Countries with and without Adjustments to Reflect NIPA Estimates, 1999-2000

LIS Income Reports: Factor Income as \% of Average Factor Income Received by 45-49 Year-olds /a/

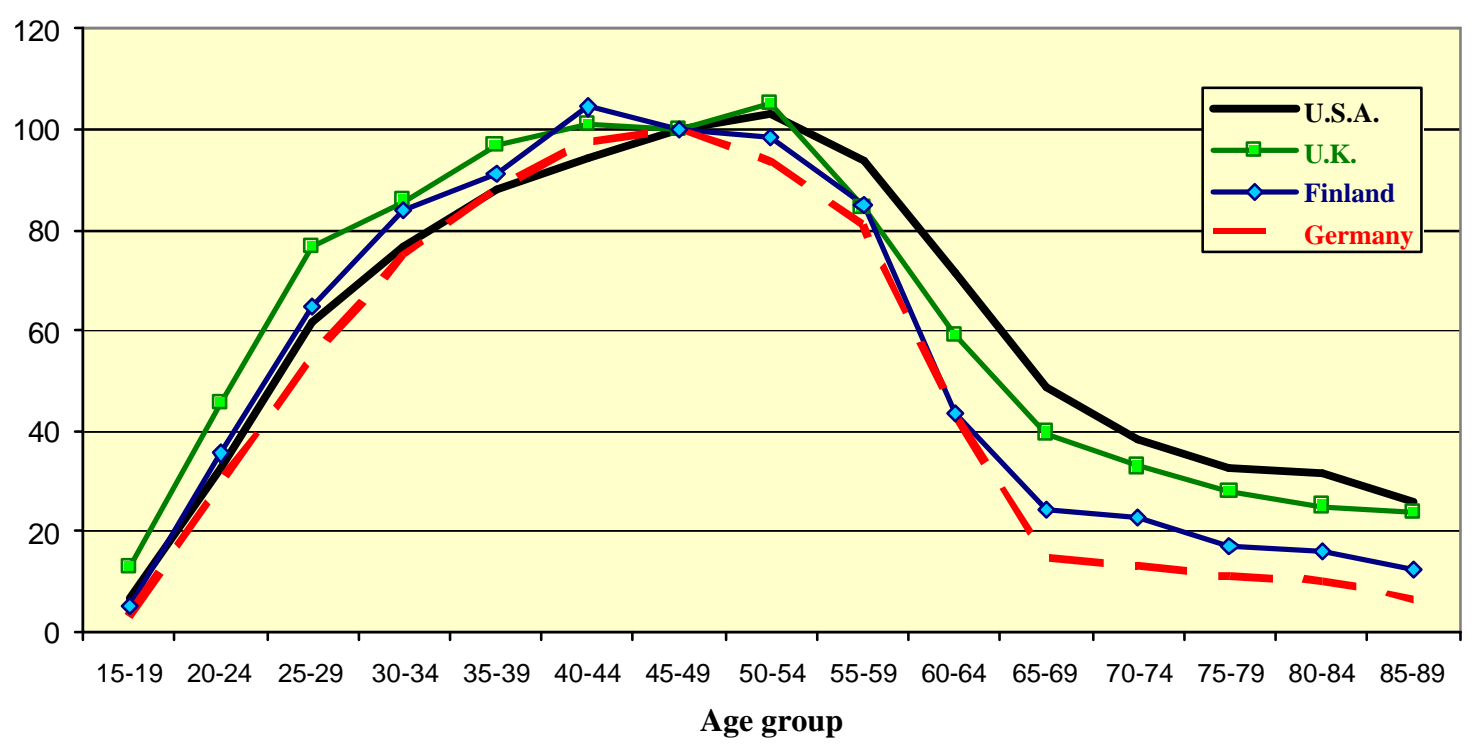

Income Reports Adjusted to NIPA: Factor Income as \% of Average Factor Income Received by 45-49 Year-olds /b/

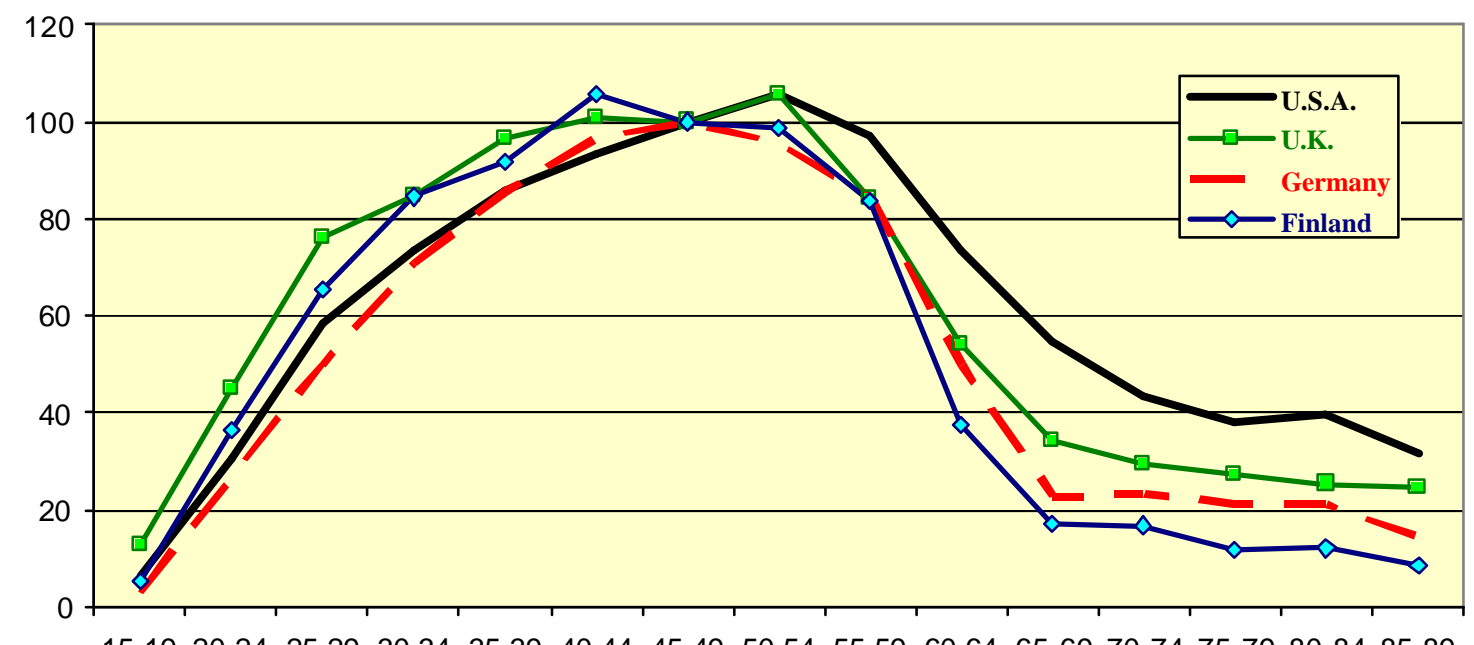

15-19 20-24 25-29 30-34 35-39 40-44 45-49 50-54 55-59 60-64 65-69 70-74 75-79 80-84 85-89

Age group

Source: Author's tabulations of LIS and NIPA data files as explained in text.

/a/ Distribution of factor incomes based on income reports without NIPA adjustment.

/b/ Distribution of factor incomes based on LIS income reports adjusted to reflect aggregate factor incomes shown in NIPA. 


\section{Figure 7. Age Pattern of Paygo Transfers in Four Countries with and without Adjustments to Reflect NIPA Estimates, 1999-2000}

LIS Income Reports: Transfers received measured as \% of Average Factor Income Received by 45-49 year-olds /a/

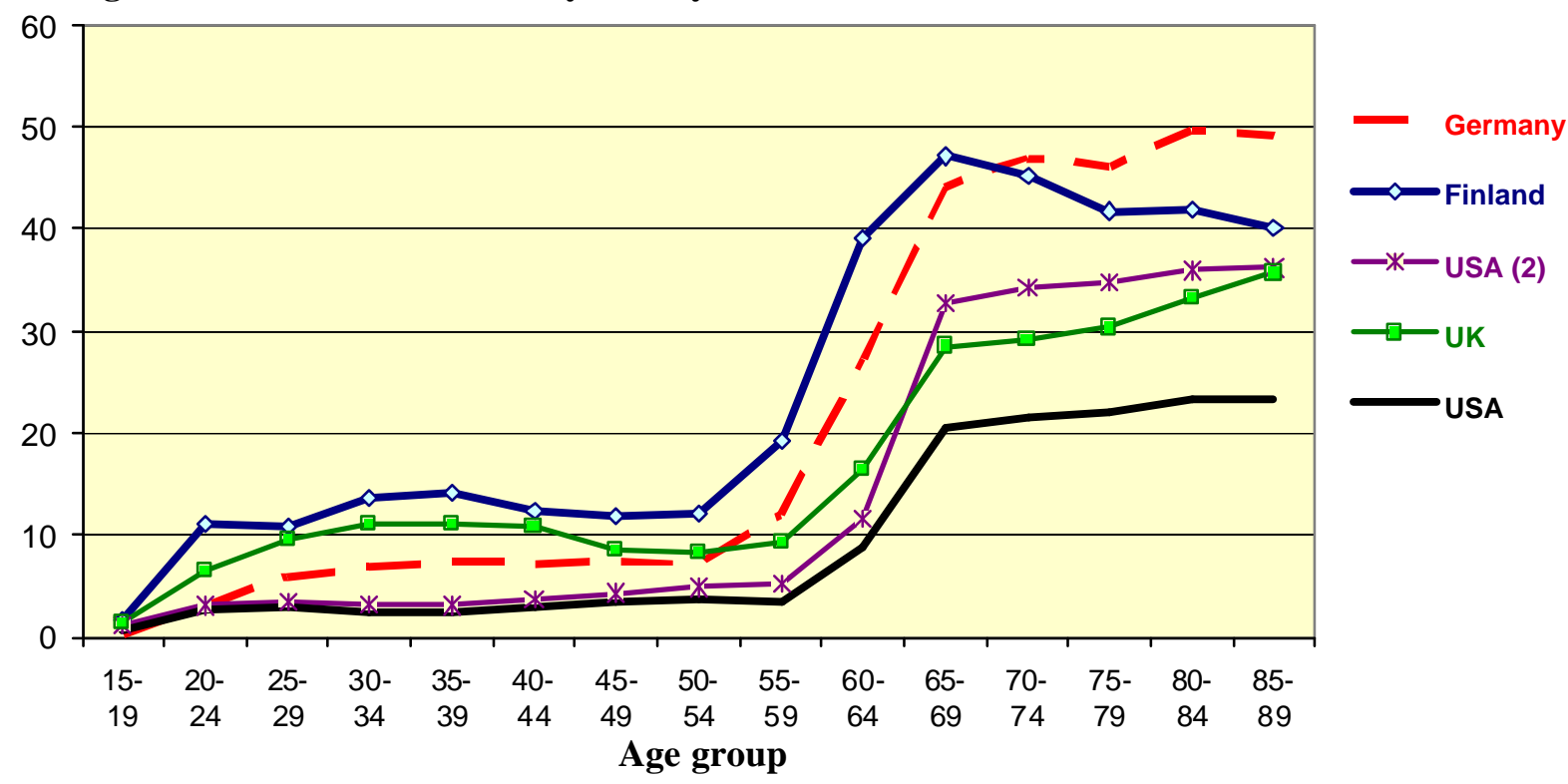

Income Reports Adjusted to NIPA: Transfers received measured as $\%$ of Average Factor Income Received by 45-49 year-olds /b/

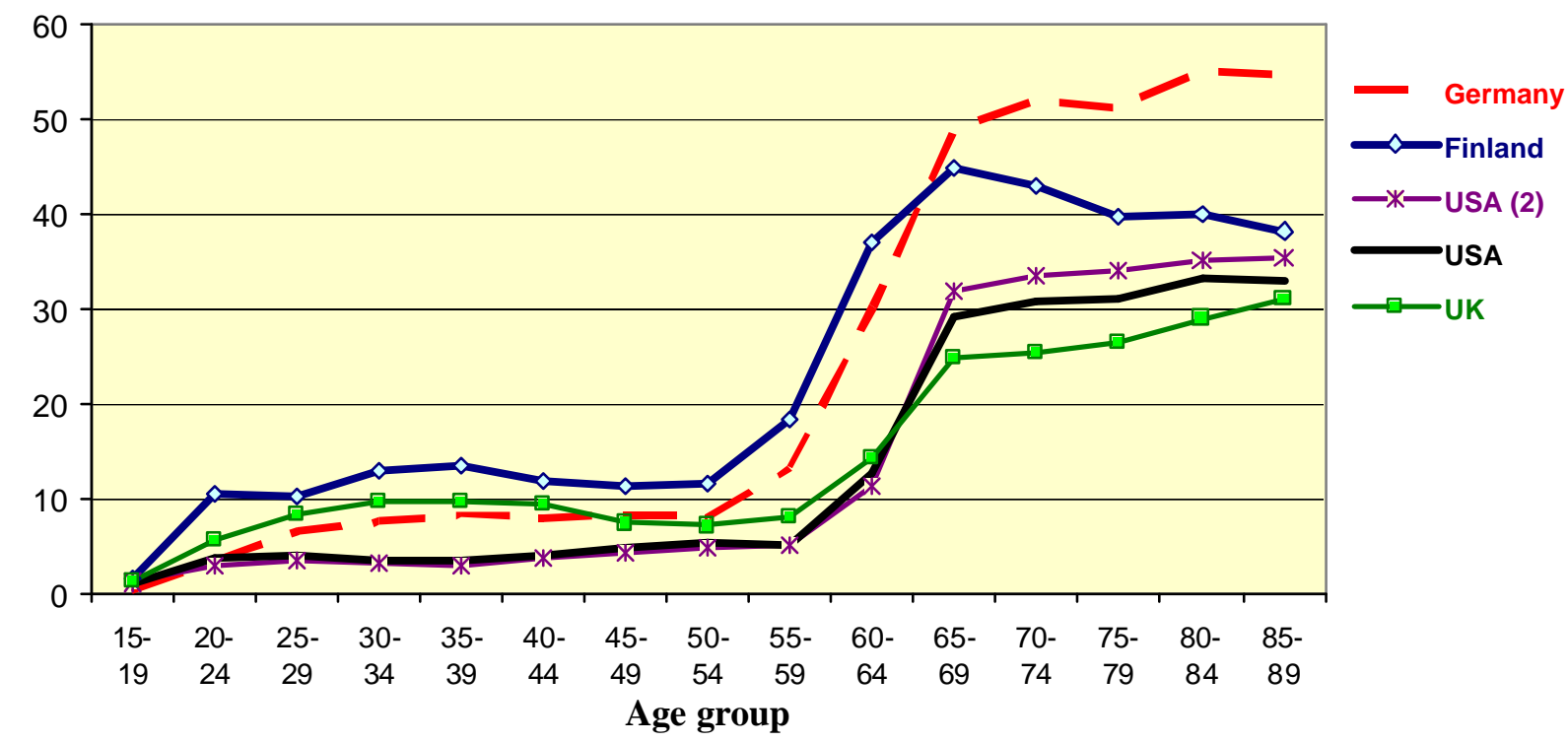

Source: Author's tabulations of LIS and NIPA data files as explained in text.

/a/ Distribution of factor incomes based on income reports without NIPA adjustment.

/b/ Distribution of factor incomes based on LIS income reports adjusted to reflect aggregate factor incomes shown in NIPA. 
Figure 8. Implied Tax on Factor Income for Paygo Transfers Assuming Identical Population Age Structure

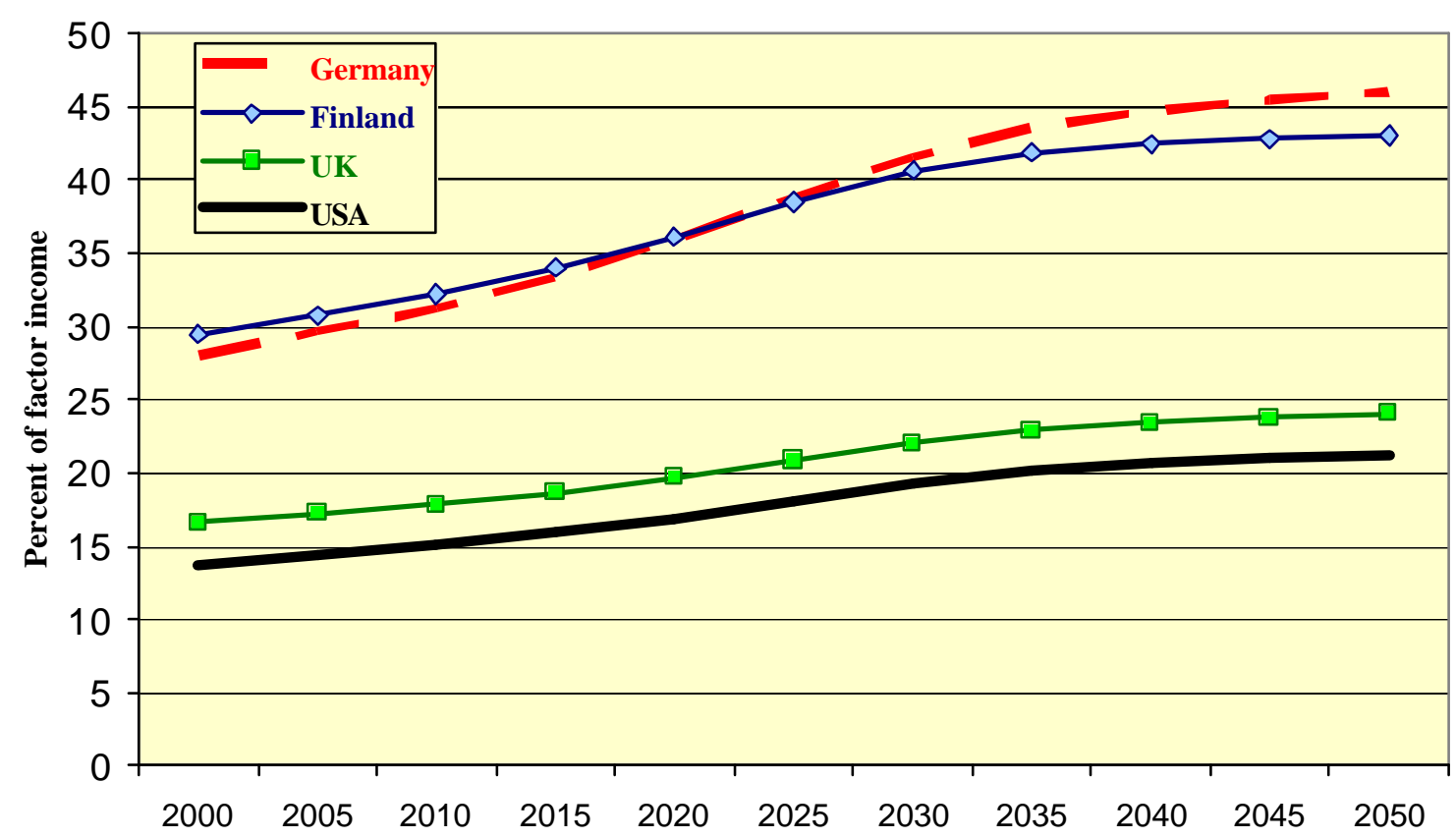

Note: Calculations based on NIPA-adjusted income amounts and standardized trend in population age profile.

Figure 9. Implied Tax on Factor Income for Paygo Transfers with Actual Population Age Structure

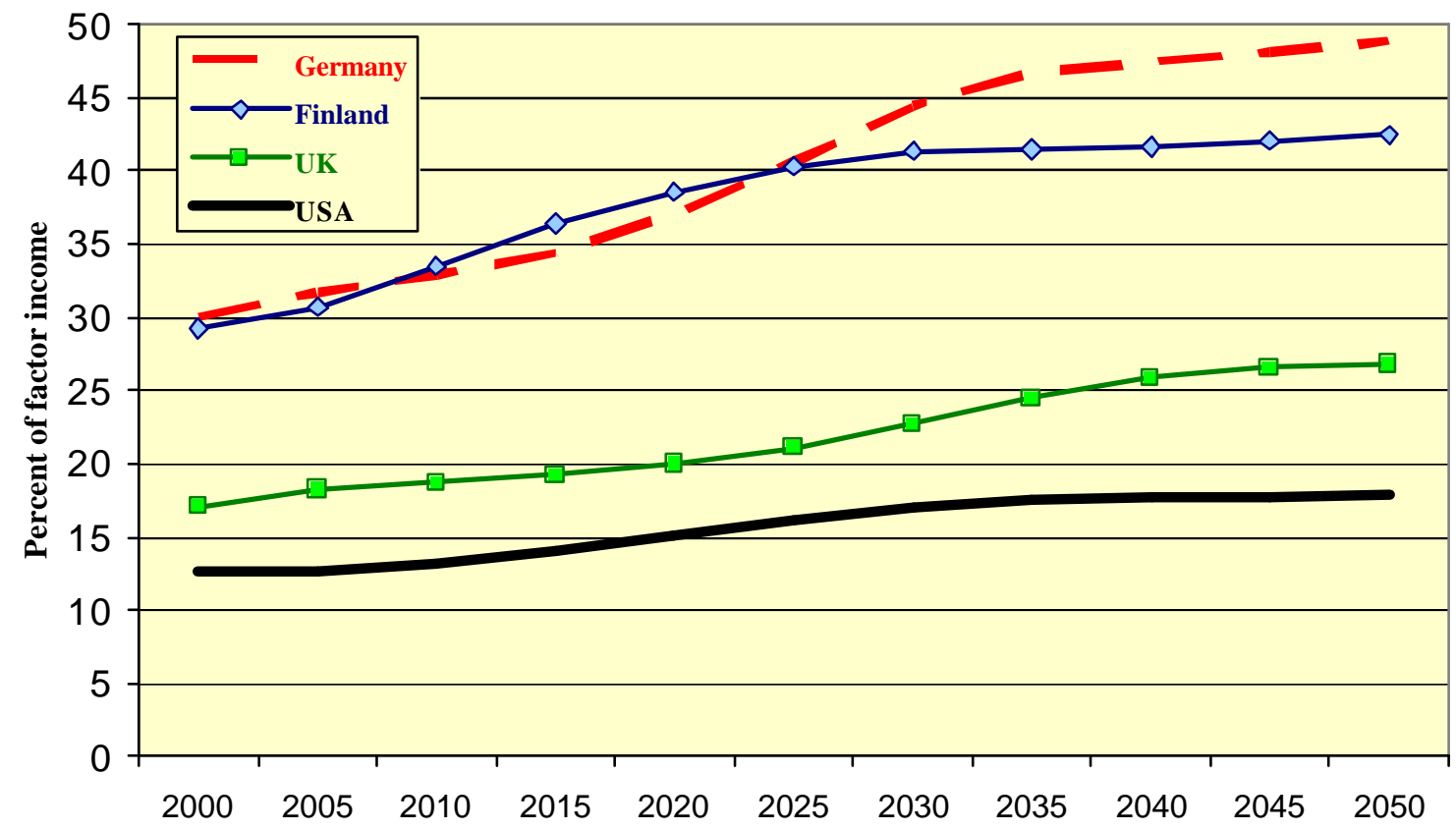

Note: Calculations based on NIPA-adjusted income amounts. 


\section{RECENT WORKING PAPERS FROM THE \\ CENTER FOR RETIREMENT RESEARCH AT Boston College}

The Age Profile of Income and the Burden of Unfunded Transfers in Four Countries: Evidence from the Luxembourg Income Study

Gary Burtless, January 2005

Projecting Immigration: A Survey of the Current State of Practice and Theory Neil Howe and Richard Jackson, December 2004

Nonearnings Income Migration in the United States: Anticipating the Geographical Impacts of Baby Boom Retirement

Peter B. Nelson, December 2004

Does Work Pay at Older Ages?

Barbara A. Butrica, Richard W. Johnson, Karen E. Smith, and Eugene Steuerle, November 2004

Poverty and Income Maintenance in Old Age: A Cross-National View of Low Income Older Women

Timothy M. Smeeding and Susanna Sandstrom, November 2004

How Does Marriage Affect the Allocation of Assets in Women's Defined Contribution Plans?

Angela C. Lyons and Tansel Yilmazer, November 2004

Why Don't Americans Save?

Barry Bosworth, November 2004

How Do Pensions Affect Expected and Actual Retirement Ages?

Alicia H. Munnell, Robert K. Triest, and Natalia A. Jivan, November 2004

Sliding Into Poverty? Cross-National Patterns of Income Source Change and Income Decay in Old Age

James M. Williamson and Timothy M. Smeeding, November 2004

The Well-Being Of Retirees: Evidence Using Subjective Data

Keith A. Bender, November 2004

All working papers are available on the Center for Retirement Research website (http://www.bc.edu/crr) and can be requested by e-mail (crr@bc.edu) or phone (617-552-1762). 